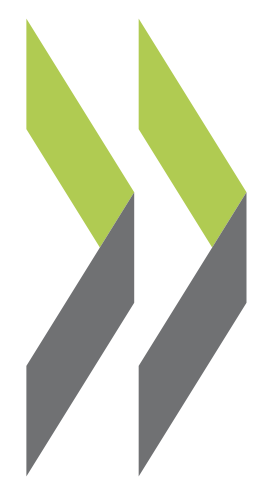

OECD Economics Department Working Papers No. 1179

\title{
Empirical Evidence on the Effects of Environmental Policy Stringency on Productivity \\ Growth
}

\author{
Silvia Albrizio,
}

Tomasz Koźluk, Vera Zipperer 
Organisation de Coopération et de Développement Économiques

Organisation for Economic Co-operation and Development

04-Dec-2014

ECONOMICS DEPARTMENT

English - Or. English

\section{EMPIRICAL EVIDENCE ON THE EFFECTS OF ENVIRONMENTAL POLICY STRINGENCY ON PRODUCTIVITY GROWTH}

ECONOMICS DEPARTMENT WORKING PAPERS No. 1179

By Silvia Albrizio, Tomasz Koźluk and Vera Zipperer

OECD Working Papers should not be reported as representing the official views of the OECD or of its member countries. The opinions expressed and arguments employed are those of the author(s).

Authorised for publication by Jean-Luc Schneider, Deputy Director, Policy Studies Branch, Economics Department.

All Economics Department Working Papers are available through OECD's Internet website at www.oecd.org/eco/workingpapers

JT03367927

Complete document available on OLIS in its original format

This document and any map included herein are without prejudice to the status of or sovereignty over any territory, to the delimitation of international frontiers and boundaries and to the name of any territory, city or area. 
OECD Working Papers should not be reported as representing the official views of the OECD or of its member countries. The opinions expressed and arguments employed are those of the author(s).

Working Papers describe preliminary results or research in progress by the author(s) and are published to stimulate discussion on a broad range of issues on which the OECD works.

Comments on Working Papers are welcomed, and may be sent to OECD Economics Department, 2 rue André-Pascal, 75775 Paris Cedex 16, France, or by e-mail to eco.contact@oecd.org

This document and any map included herein are without prejudice to the status of or sovereignty over any territory, to the delimitation of international frontiers and boundaries and to the name of any territory, city or area.

\section{(C) OECD (2014)}

You can copy, download or print OECD content for your own use, and you can include excerpts from OECD publications, databases and multimedia products in your own documents, presentations, blogs, websites and teaching materials, provided that suitable acknowledgment of OECD as source and copyright owner is given. All requests for commercial use and translation rights should be submitted to rights@oecd.org 
ECO/WKP(2014)75

\section{ABSTRACT/RÉSUMÉ}

\section{Empirical evidence on the effects of environmental policy stringency on productivity growth}

This paper investigates the impact of changes in the stringency of environmental policies on productivity growth in OECD countries. Using a new environmental policy stringency (EPS) index, it estimates a reduced-form model of multi-factor productivity growth, where the effect of countries' environmental policies varies with pollution intensity of the industry and technological advancement. A multi-layer analysis provides insights at the aggregate economy, the industry and the firm level. At the aggregate economy level, a negative effect on productivity growth is found one year ahead of the policy change. This negative "announcement effect" is offset within three years after the implementation. At the industry level, a tightening of environmental policy is associated with a short-term increase in industry-level productivity growth, for the most technologically advanced country-industry pairs. This effect diminishes with the distance to the global productivity frontier, becoming insignificant at larger distances. At the firm level, only the technologically most advanced firms show a positive effect on productivity growth from a tightening of environmental policies, while a third of firms, the less productive ones, experience a productivity slowdown.

JEL classification codes: O47, O44, Q50, Q58.

Keywords: environmental policy stringency, environmental policies, environmental regulation, Porter hypothesis, multifactor productivity.

\section{$* * * * * * * * * * * * * * * * * * * * * * * * * * * * * * * * *$ \\ Données empiriques sur les effets de la sévérité des politiques environnementales sur la croissance de la productivité}

Ce document étudie l'impact qu'ont les modifications de la sévérité des politiques environnementales sur la croissance de la productivité dans les pays de l'OCDE. À l'aide d'un nouvel indice de sévérité des politiques environnementales (SPE), il estime un modèle en forme réduite de la croissance de la productivité multifactorielle, dans lequel l'effet des politiques environnementales des pays varie selon l'intensité de pollution de l'industrie et le degré d'avancement technologique. Une analyse multicouche donne des indications au niveau macro-économique, à celui de l'industrie et à celui des entreprises. Au niveau macro-économique, un effet négatif sur la croissance de la productivité est observé un an avant la modification des politiques. Cet «effet d'annonce » négatif est compensé dans un délai de trois ans après la mise en œuvre. Au niveau de l'industrie, le durcissement des politiques environnementales est associé à une accélération à court terme de la croissance de la productivité pour les couples pays-industrie les plus avancés d'un point de vue technologique. Cet effet diminue jusqu'à devenir insignifiant à mesure qu'on s'éloigne de la frontière de productivité mondiale. Au niveau des entreprises, enfin, seules celles qui sont les plus en pointe du point de vue technologique voient la croissance de leur productivité influencée de façon positive par un durcissement des politiques environnementales, tandis qu'un tiers des entreprises, en l'occurrence les moins productives, accusent un ralentissement de leur productivité.

Classification JEL : O47, O44, Q50, Q58.

Mots clés : sévérité des politiques environnementales, réglementations environnementales, hypothèse de Porter, productivité multifactorielle. 


\section{TABLE OF CONTENTS}

\section{EMPIRICAL EVIDENCE ON THE EFFECTS OF ENVIRONMENTAL POLICY STRINGENCY ON

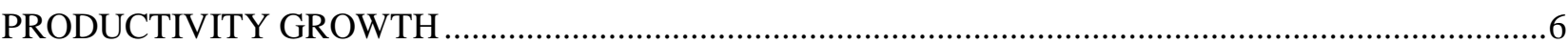

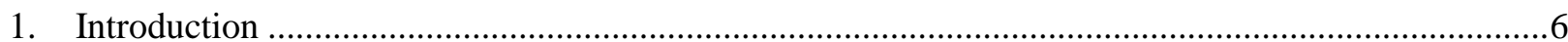

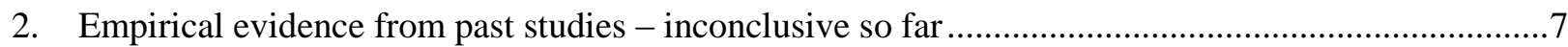

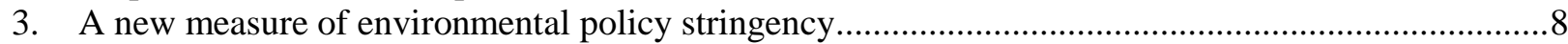

4. Environmental policies and productivity - what the descriptive statistics say ..................................10

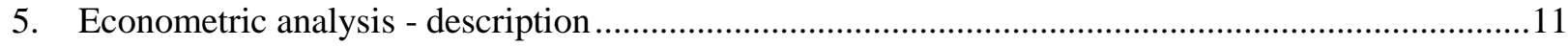

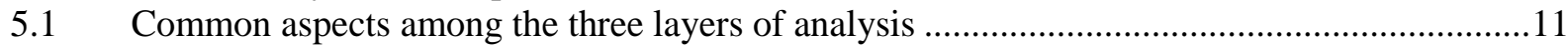

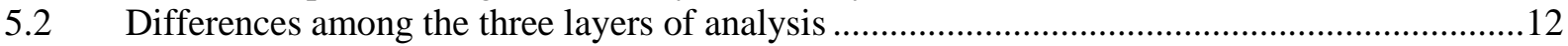

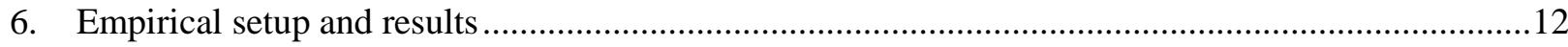

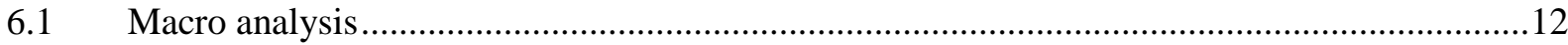

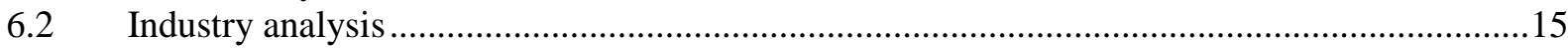

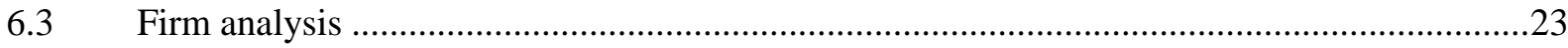

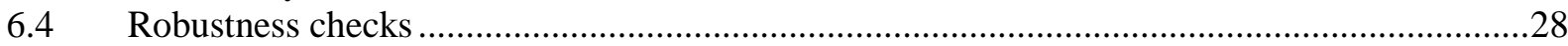

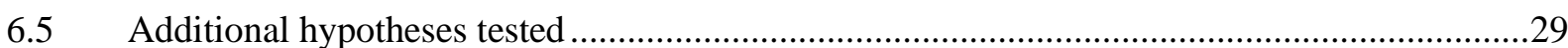

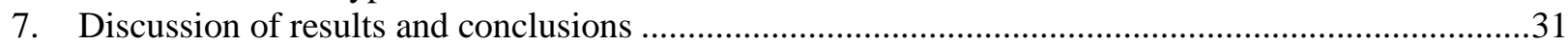

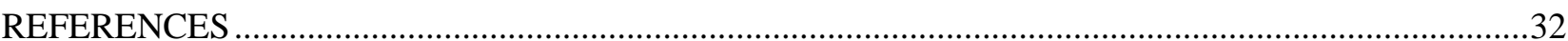

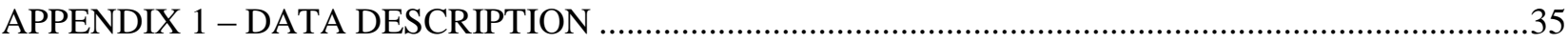

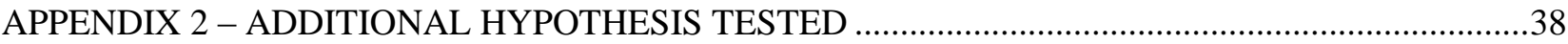

\section{Tables}

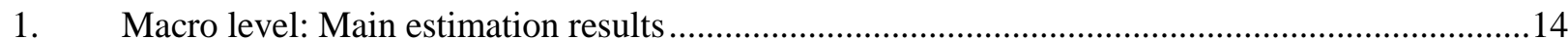

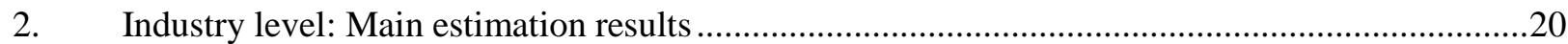

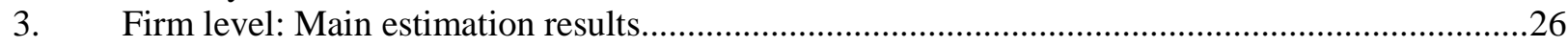

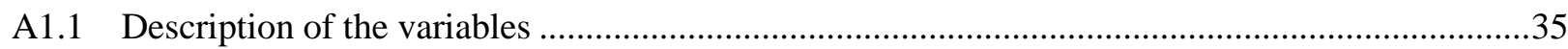

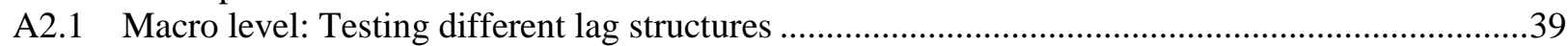

A2.2 Macro level: Market-based versus non-market instruments ...................................................40

A2.3 Industry level: Market-based versus non-market instruments ...................................................41

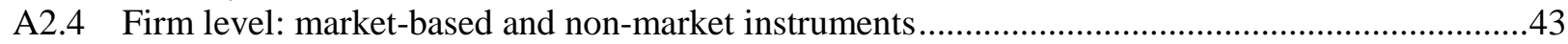

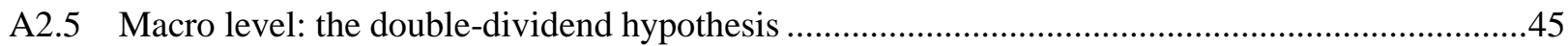

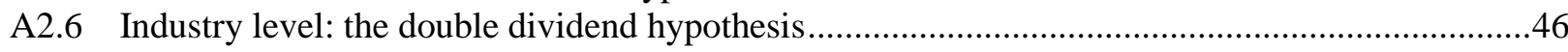

\section{Figures}

1. Structure of the Environmental Policy Stringency (EPS) indicator ...............................................

2. Distribution of MFP growth by countries' environmental policy stringency (EPS).....................10

3. Simulated effects on macro level productivity growth ..............................................................15

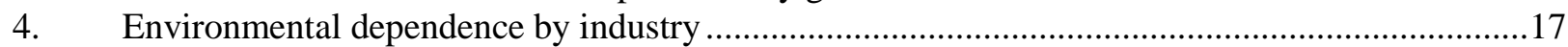

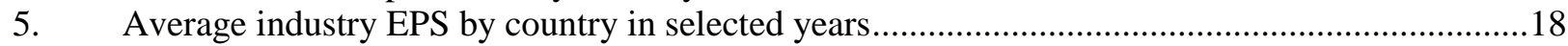

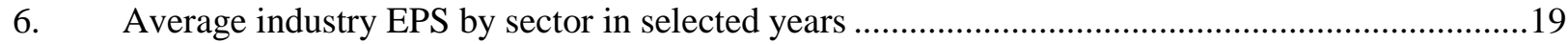

7. Distribution of industries with respect to the distance to the frontier .........................................21

8. Marginal effect of an EPS tightening by the distance to frontier - industry level .......................22

9. Simulated effects of EPS tightening on industry MFP growth ................................................23

10. Environmental dependence by 2-digit industry classification ...............................................25 
11. Marginal effect of an EPS tightening by distance to frontier - firm level .................................27

12. Distribution of distance to the frontier full sample versus larger firms .....................................28

13. Marginal effect: market-based versus non-market EPS tightening .............................................30

A.2.1 Distribution of industry-EPS changes by instrument type and distance to the frontier ................42 


\title{
EMPIRICAL EVIDENCE ON THE EFFECTS OF ENVIRONMENTAL POLICY STRINGENCY ON PRODUCTIVITY GROWTH
}

\author{
By \\ Silvia Albrizio, Tomasz Koźluk and Vera Zipperer ${ }^{1}$
}

\section{Introduction}

1. Environmental policies are likely to affect not only environmental outcomes, but also economic performance and wellbeing. Over the last twenty years, governments in OECD countries have implemented a wide range of environmental policies with the aim of improving environmental conditions. Policy instruments are often based on price mechanisms (market-based instruments), increasing the opportunity costs of pollution and environmental damage, or take the form of command-and-control policies, enforcing environmental standards (non-market instruments). Inevitably, environmental policies affect production processes, resource reallocation, capital investment, labour intensity and innovation incentives.

2. This paper provides a first step in the analysis of economic effects of environmental policy stringency by focusing on multi-factor productivity (MFP) growth. The building blocks of GDP per capita - a traditional measure of economic performance and income in an economy - are capital intensity, labour participation, human capital and multifactor productivity. Effects of environmental policies on capital and productivity are likely to be of a direct nature, for instance through changes in relative input costs and innovation incentives. The effects on labour participation and human capital may rather be indirect, through e.g. the improved state of the environment and the related improvement of health.

3. A priori, it is unclear how and if productivity growth will be affected by more stringent environmental policies. Additional costs of polluting can induce firms to devote resources towards pollution abatement or innovation. In a scenario where the output level stays constant but more investment is undertaken, e.g. into abatement capital, firm-level productivity growth is likely to slow down, at least in the short term. At the same time, incentives for innovation, efficiency improvements and within-firm reallocation may lead to higher productivity - in line with the so-called Porter Hypothesis (Porter, 1991; Porter and van der Linde, 1995). At higher levels of aggregation, such as industry and country levels, the direction of the effect will also depend on resulting reallocation among firms - environmental policies may cause polluting firms to exit the market, outsource their activities or relocate abroad (in line with the pollution haven hypothesis). If environmental policies increase barriers to entry, to competition or trade frictions, competitive pressures will be reduced, firms' entry-exit dynamics will slow down and aggregate productivity will decrease. Understanding the impact of environmental policies on MFP growth is therefore crucial for the design of broader policy packages to avoid negative side-effects on economic growth. However, empirical evidence on the effects of environmental policies on productivity growth has been scarce, context-specific and largely inconclusive.

1. This paper is part of the joint work of the Economics Department and Environment Directorate on Environmental Policies and Economic Outcomes. The authors are members of the Economics Department and Environment Directorate of the OECD. They would like to thank Jean-Luc Schneider, Giuseppe Nicoletti, Shardul Agrawala, Nick Johnstone, Chiara Criscuolo, Peter Gal, Carlo Menon, Jehan Sauvage, Oystein Skeie and Enrico Botta, for their useful comments and suggestions. Special thanks go to Catherine Chapuis for statistical assistance and to Ines Gomez Palacio, Sarah Michelson and Zoey Verdun for editorial support. 
4. In an attempt to fill some of the gaps in the literature, this paper conducts an empirical analysis of the effect of environmental policy stringency (EPS) on country, industry and firm-level productivity growth in a panel of OECD countries. A new dataset on environmental policy stringency allows analysing a broad cross-country dimension over two decades - a novelty with respect to previous research. The new EPS measure, developed by Botta and Koźluk (2014), is based on the aggregation of quantitative and qualitative information on selected environmental policy instruments into one comparable, country-specific proxy of environmental policy stringency.

5. Results suggest that more stringent environmental policies do not harm aggregate productivity growth. At the macro economy level, the analysis shows that after an initial fall in productivity growth prior to the implementation of more stringent policies, productivity growth is boosted in the subsequent years. The net effect in the medium run turns out negligible. At the industry level, a tightening in environmental policies is found to have a positive short-term effect on productivity growth for the most technologically advanced country-industry pairs. This positive effect diminishes with the distance to the global technology frontier and vanishes completely for the least productive country-industry pairs. This finding is only partially confirmed at the firm level: only one-tenth of the firms are able to reap some productivity gains after a tightening of environmental regulation. About one-third of the firms, the least productive ones, face a negative effect on productivity growth in the short run.

6. This paper is structured in the following way. Section II provides a brief overview of the relevant literature with empirical findings on the effects of environmental policies on productivity growth at the macro, industry and firm level. Section III describes the new measure of environmental policy stringency. Section IV presents descriptive evidence on the relationship between multifactor productivity (MFP) growth and environmental policy stringency. In section $\mathrm{V}$, the empirical methodology is explained, with a particular focus on the common aspects across the three layers of the analysis (macro, industry and firm level). Section VI is divided into three parts, according to the level of analysis: macro, industry and firm level. Each part presents details of the econometric specification, the results for the respective level, robustness checks and additional hypothesis tested. The paper concludes with a summary of the main channels through which environmental policies may affect productivity growth, highlights the most relevant policy implications and sketches some proposals for future research. Appendixes describe the data used and provide more details on estimation results.

\section{Empirical evidence from past studies - inconclusive so far}

7. Empirical studies of the effects of environmental policies on productivity growth at the aggregate economy level are few and inconclusive (see Koźluk and Zipperer, 2014). The main constraints faced by the researchers are related to data and identification issues: good proxies for environmental policy stringency on a comparable cross-country basis are missing and identification strategies based on the introduction of one policy in several countries at the same time are not feasible due to a scarcity of such examples and multiple interfering factors. All of the existing studies on the macro level use a distancefunction framework which effectively means they focus on multifactor productivity adjusted for (selected) pollutant emissions. Scenario analyses, which compare a business-as-usual scenario with the introduction of an environmental policy leading to constant levels of bad outputs, yield either negative (Jeon and Sickles, 2004) or slightly positive (Wu and Wang, 2008) results on adjusted MFP growth. Studies using the ratification of the UNFCCC as proxy for environmental policy stringency obtain results ranging from positive (Yörük and Zaim, 2005) to negative (Wu and Wang, 2008).

8. Among industry-level studies, the results are relatively few and problematic. Older studies, which tend to find negative effects of environmental regulations on productivity growth tend to suffer from problems of identification and are generally not very robust. Notable contributions include attempts to explain the US productivity slowdown in the 1970s with environmental regulation 
(Gray, 1987; Barbera and McConnell, 1990), and Dufour (1998) who looks at Canadian industries in the 1980s. More recent work, based on longer time series or case studies, find an aggregate positive or null effect. Hamamoto (2006) finds that environmental command and control regulations led to an increase in innovation (proxied by R\&D spending) and consequently to an increase in productivity growth in a sample of five Japanese manufacturing sectors over 20 years. Yang et al. (2012) find similar effects of environmental policy tightening on Taiwanese manufacturing sectors while for Quebec, Lanoie et al. (2008) find a short run negative effect, due to the additional costs imposed by the tighter environmental regulation, outweighed by a subsequent positive effect. The sole study with an international dimension, Alpay et al. (2002), finds no effect on productivity growth in the US food manufacturing sector (where environmental policies are proxied by pollution abatement and control expenditures) but a positive effect in Mexico (with environmental policies proxied by the frequency of environmental inspections).

9. Evidence from firm or plant level studies shows a negative but not very robust effect of environmental regulation on productivity growth. Most of the studies compare productivity growth between regulated and non-regulated firms or plants, finding negative (Gollop and Roberts, 1983; Smith and Sims, 1985) or insignificant (Berman and Bui, 2001) results. These early studies often neglected including firm or plant specific characteristics in the analysis. Becker (2011) and Gray and Shadbegian (2003) show the importance to include such firm specific characteristics and find negative effects of environmental regulation on productivity growth. The effect of environmental regulation might also depend on the type of pollutant regulated - Greenstone et al. (2012) identify a negative effect of ozone and particulates emission regulations. They find sulphur dioxide emission regulations did not have a significant effect and carbon monoxide regulations may have even increased productivity growth. Aside from the methodological issues of including firm characteristics in the analysis, the firm and plant level studies suffer from a lack of generality, as usually very specific regulations or industries are analysed in a single country setting.

\section{A new measure of environmental policy stringency}

10. Available cross-country measures of environmental policies often lack a meaningful timedimension which renders them less suitable for empirical analyses. Only a handful of studies attempt to build cross-country measures of environmental policies. Dasgupta et al. (1995) were among the first ones to develop a composite, cross-country indicator based on reports prepared for the United Nations Conference on Environment and Development. This indicator was only compiled for one year. A similar problem arises for the CLIMI Index (Climate Laws, Institutions and Measures Index) produced by the EBRD. The CLIMI index builds on UN country reports and UNFCCC submissions reports, but was only constructed for the year 2010. Finally, the World Economic Forum (WEF) measures capture perceptions of environmental policy stringency through a survey of business executives. In contrast to the measures mentioned before, the WEF index is available starting in the early 2000s, but by construction is more suitable for cross-country rather than across-time comparisons (see Botta and Koźluk, 2014 for a more detailed discussion).

11. The analysis in this paper is based on a new composite index of environmental policy stringency (EPS) developed by the OECD (for a detailed description see Botta and Koźluk, 2014). The EPS composite index covers 24 OECD countries over the period 1990-2012 and summarises environmental policy stringency across selected instruments. ${ }^{2}$ It reduces a complex of multidimensional policies into a comparable country-specific measure similarly to indexes developed in other fields of regulation, such as

2. With respect to previous versions, New Zealand was excluded from the analysis in this paper, as due to specific aspects of New Zealand environmental policies it was not possible to arrive with a satisfactory proxy under the time constraints. Work is underway to include New Zealand (and other countries) in a later, extended vintage of the EPS. 
the OECD product market regulation, the OECD employment protection legislation (Nicoletti et al., 2000 and Conway et al., 2006) or the competition law and policy (Hoj, 2007; Alemani et al., 2013) and the burdens to businesses (the World Bank Doing Business Indicators or the WEF Global Competitiveness Index).

12. The indicator is based on the taxonomy developed by De Serres et al. (2010) and aggregated along a tree structure where the sub-components are all weighted equally (Figure 1). A market-based subcomponent groups instruments which assign an explicit price to the externalities (taxes: $\mathrm{CO}_{2}, \mathrm{SO}_{\mathrm{X}}, \mathrm{NO}_{\mathrm{X}}$, and diesel fuel; trading schemes: $\mathrm{CO}_{2}$, renewable energy certificates, energy efficiency certificates; feedin-tariffs; and deposit-refund-schemes), while the non-market component clusters command-and-control instruments, such as standards (emission limit values for $\mathrm{NO}_{\mathrm{X}}, \mathrm{SO}_{\mathrm{X}}$, and $\mathrm{PM}$, limits on sulphur content in diesel), and technology-support policies, such as government R\&D subsidies.

Figure 1. Structure of the Environmental Policy Stringency (EPS) indicator

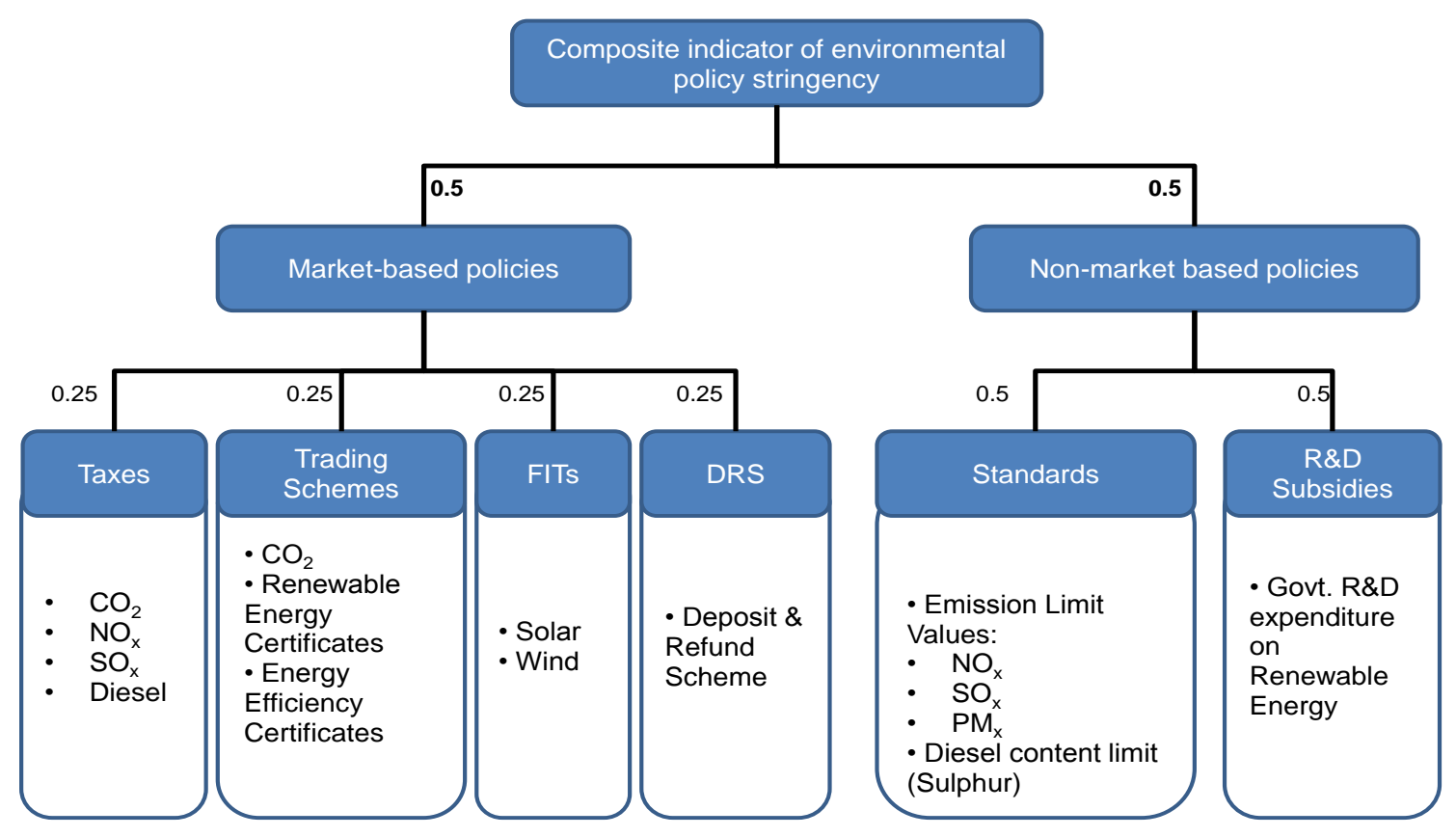

Source: Botta and Koźluk (2014)

13. The indicator ranges from 0 to 6 with higher numbers being associated with more stringent environmental policies. The indicator focuses on regulation in the energy sector ${ }^{3}$, transport regulations and deposit and refund schemes. It covers primarily climate and air pollution policies.

14. The sectoral coverage of environmental policies is clearly limited, but also has several important advantages. Firstly, it focuses on upstream sectors, present in all countries and of comparable economic importance with respect to other sectors. In most countries such sectors are characterised by high pollution

3. The energy sector is identified as those activities that pertain to the production, transmission and distribution of electricity, gas and steam (ISIC rev. 4 code D 35), though in practice many of the environmental policies may extend to broader sectors of the economy - as in the case of the EU ETS, which covers large industrial installations. For a detailed discussion of the cautions regarding the EPS indicator, see Botta and Koźluk, (2014). 
intensity and regulated by well-identified and comparable types of policy instruments (see Botta and Koźluk, 2014). A comparison with other available measures of environmental policy stringency (e.g. WEF index, CLIMI) suggests that the EPS is a good proxy of the countries' overall environmental policy stringency. ${ }^{4}$ In the econometric analysis, using an energy, transport and waste derived EPS proxy helps to decrease endogeneity concerns as the EPS can be seen as a good instrument for policy stringency for the entire country.

\section{Environmental policies and productivity - what the descriptive statistics say}

15. Over 1990-2009 countries with the most stringent environmental policies have generally seen higher industry MFP growth than those with the most lax policies. Figure 2, left panel, shows that the median of annual pooled industry level MFP growth rates for the most stringent countries is higher (i.e. located to the right) than for the less stringent countries. A similar finding holds when looking at changes in environmental policy stringency (Figure 2, right panel). Countries that experienced more environmental policy tightening have experienced higher MFP growth than countries with less tightening. While this would suggest that environmental policy stringency is associated with higher productivity growth, it can only serve as a motivation for a rigorous analysis, as many frictions beyond environmental policy stringency influence productivity.

Figure 2. Distribution of MFP growth by countries' environmental policy stringency (EPS)

1990-2009
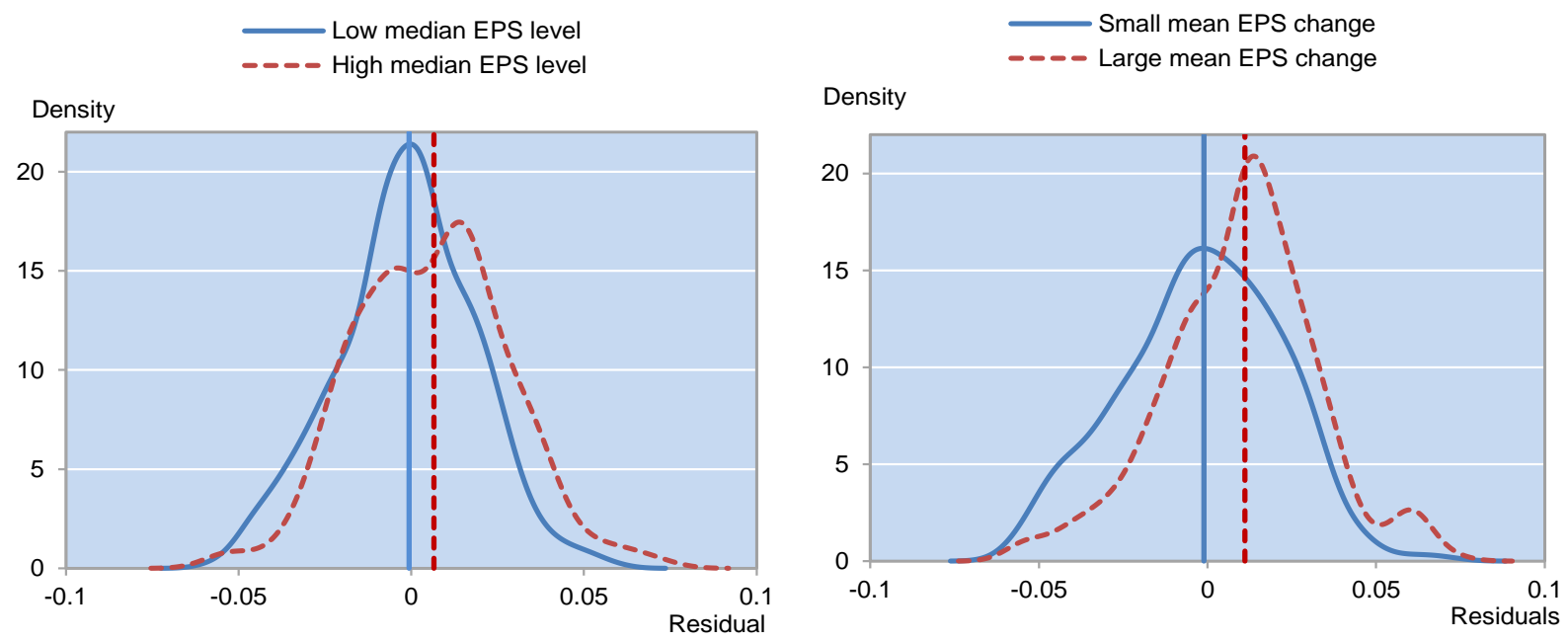

Note: The left-hand graph presents the MFP growth distribution of the three countries with highest median EPS levels (dotted line) versus the distribution in the three countries with the lowest median EPS levels. The right-hand graph shows the MFP growth distribution of the three countries with the highest average EPS increases over the sample versus the three countries with the lowest.

4. Such an assumption is not directly testable, due to the fact that environmental policy stringency cannot be directly observed. Botta and Koźluk (2014) provide several attempts to corroborate the EPS with other available measures, such as perceptions on environmental policy stringency (WEF), the Climate Laws, Institutions and Measures Index (EBRD, 2011), or other more crude proxies and find high significant correlations with most of them. The alternative measures cannot be used directly in our analysis, as most either lack a time series, or have a time dimension that is not meaningful (WEF). 


\section{Econometric analysis - description}

\subsection{Common aspects among the three layers of analysis}

16. In order to investigate the effects of environmental policy stringency on productivity growth, a consistent approach is adopted throughout the three levels of analysis: macro, industry and firm level. It is based on a reduced-form model of multifactor productivity growth, where productivity growth depends on the firm's ability to adopt innovative and efficient technologies available in the market (technological catch-up) and on firms' ability to innovate (technological pass-through) (Acemoglu et al., 2006; Aghion and Howitt, 2006; Nicoletti and Scarpetta, 2003; Bourles et al., 2013; Westmore, 2013). ${ }^{5}$ Previous literature using this productivity specification has stressed that regulations may affect the dynamic innovation process, reducing firm and industry productivity growth if the regulation design is inappropriate. In line with this research, a differential effect of environmental regulation on MFP growth is allowed depending on the distance to the global frontier. The most technologically advanced firms are likely to have more resources to invest into R\&D or knowledge-based capital, and scale up energy efficiency gains from abatement. They may also be better suited to adapt to change in business due to an EPS tightening - due to access to technology, markets or managerial capacity. Less advanced firms, which are likely to be small incumbents or new entrants, may find burdensome to comply with the new regulation, for instance due to the relatively higher investments required to adopt cleaner technologies, exchanging equipment.

17. There are a number of additional common features across the three-layer setup:

- Focus on changes in stringency rather than levels of stringency. The analysis focuses on the change of the EPS indicator rather than levels. Even though the level of environmental stringency might have economic effects, for instance on trade patterns, effects on productivity growth are likely to be driven by changes in the environmental policy stringency. When only considering one country, a static level of environmental regulation per se (seen as a difference in relative prices of inputs) will not induce changes in the production processes of firms. However, firms are likely to react to new policy implementations by investing into abatement capital or reorganising their production. From an econometric perspective EPS levels empirically resemble a non-stationary process, which may be problematic, while the first differences are stationary. ${ }^{6}$

- Choosing lag structures to account for various time horizons of economic effects. The productivity effect of policy changes might be lagged in time. Factors such as derogations, delayed implementation of legislative processes, or specific characteristics of the investments (time to build, learning by doing, etc.), may affect the time of the adjustment and, consequently, the time and the horizon of the economic effects. Firms may invest into new capital before the policy is implemented, but only reap gains in productivity in later years. Less efficient firms may also exit, cut or outsource activity, not being able to compete under the additional requirements - which may also take time. After testing for different lags structures, a 3-year moving average has been chosen for the change in EPS and has been adopted across the three level of analysis (macro, industry and firms) in order to have a common and consistent structure (see Table A2.1 for some alternative results). This moving

5. Frontier observations are excluded from the econometric estimation in all the three layers of analysis.

6. In principle, the indicator values of the EPS are bounded between zero and six and therefore the EPS cannot have a unit root. 
average includes the first, second and third lag of the change in EPS and it is used also in the interaction term with the distance to frontier.

- Testing for forward looking behaviour. An introduction or a change in stringency of environmental policy instruments is often known or expected in advance - before the actual implementation. Thus the effect of a tightening EPS on MFP growth in period $t$ might not be captured by looking only at the following periods. If policymakers credibly announce the upcoming change of an environmental policy, firms may start investing into the capital and labour to comply with the new policy before the actual implementation. Different lead structures have been tested to account for this anticipation effect, and a 3-year moving average specification has been adopted, mirroring the lag structure. This moving average includes the first, second and third lead of the change in EPS.

\subsection{Differences among the three layers of analysis}

18. Exploiting different levels of aggregation (macro, industry and firm) can provide insights on the heterogeneity of the effect, as well as on the different channels through which environmental policies influence MFP growth. In this regard, the industry and the firm-level analysis allow for studying the effect of EPS depending on the individual industries' 'environmental dependence'. The underlying assumption is that higher environmental dependence (proxied by pollution intensity) increases the industries' exposure to country-level environmental regulation and hence the potential economic effects of the latter. To account for this feature the EPS index is interacted with an index of pollution intensity of the industry (the approach resembles that of Rajan and Zingales, 1998, for financial dependence).

19. To identify the effect of environmental policy stringency we exploit both cross-sectional and time variation. The analysis focuses on absolute effects, and hence differs somewhat from the basic differencein-difference setup employed in Bourlès et al., (2013). Country-time fixed effects are not included in the industry and firm analysis, but a comprehensive range of time and country-level controls are used. ${ }^{7}$ In the same spirit, country-industry fixed effects are applied to industry and firm level analysis.

\section{Empirical setup and results}

\subsection{Macro analysis}

20. The baseline specification estimated at the aggregate economy level takes the following form:

$$
\Delta \ln M F P_{c t}=\alpha_{1}+\sum_{j=-k}^{n} \alpha_{2 \mathrm{j}}\left(\Delta E P S_{c t-j}\right)+\alpha_{3} g a p_{c t-1}+\alpha_{4} \Delta \ln \widetilde{M F P}_{t}+x_{c t} \gamma+\eta_{t}+\delta_{c}+\epsilon_{c t}
$$

where:

- $\quad \Delta \ln M F P$ is the growth rate of multi-factor productivity for each country c.

- $\triangle E P S$ denotes the change in the indicator of environmental policy stringency (tested with different lag structures).

7. In the presence of country-time dummies, in the industry and firm level analysis, the identifying variation would come from the difference in industry exposure to environmental regulation, relative to the general effect (captured by country-time dummies) which would be of main interest of this study. Therefore country and industry fixed effects are preferred. 
- The third term reflects the technological catch-up effect (modelled as the distance in the level of MFP between the individual country and the leader), gap $=\ln \left(\frac{\widetilde{M F P}}{\mathrm{MFP}_{\mathrm{c}}}\right)$.

- $\quad \Delta \ln \widetilde{M F P}_{t}$ is the growth in the leader MFP and represents the technological pass-through. ${ }^{8}$

- $\quad \boldsymbol{x}_{\boldsymbol{c t}}$ is a vector of several country control variables, which is explained further below.

- Finally, aside from the above, the specification controls for a common time trend, the financial crisis, output gap and country fixed effects $\left(\delta_{c}\right)$.

21. Data for MFP are taken from Johansson et al. (2013). The MFP is derived as the Solow residual from a production function which includes physical capital, labour and human capital as production factors. The underlying human capital stocks are constructed using average number of years of schooling across the population aged 25-64 (Bouis et al., 2011).

22. The model is estimated for 19 OECD countries over the 1990-2010 period. The panel is unbalanced, reflecting data availability. ${ }^{9}$ In the baseline specification used in the analysis, the following control variables are included (a detailed description of the control variables as well as their sources can be found in Appendix 1): the growth rate of hours worked per employee, the output gap, dummies for the crisis years 2007 and 2008, and a common time trend. The following are used as additional control variables outside the baseline specification: government primary balance, business R\&D expenditure, trade openness, industry share in total activity, employment protection legislation (EPL), product market regulation (PMR) and the change in the real oil price.

\subsubsection{Main results}

23. The estimation results with a three-year moving average of the changes in environmental policy stringency are presented in Table 1 (specification 1 and 2). On average, there is a positive effect of a tightening of environmental policy on MFP growth. The effect is more significant when controlling for covariates. The overall estimation results of the specification and most controls (output gap, change in hours worked, R\&D spending) are in line with previous findings in terms of the significance of the growth rate of the leader country and the technological gap term as well as the size of the coefficients.

24. Environmental policy tightening does not hinder or accelerate technological catch up at the economy-wide level. Specifications 3 and 4 in Table 1 include an interaction term of the change in EPS with the technology gap ( $\triangle \mathrm{EPS} * \mathrm{DTF})$ and show that countries which are further away from the frontier do not face a significantly different effect due to a change in environmental regulation than countries close to the frontier. The inclusion of this interaction effect reduces the significance of the overall effect of the EPS perhaps due to multicollinearity among explanatory variables.

25. Introducing a lead effect of future changes in environmental policy (column 5 and 6, Table 1) suggests that there is a negative effect of a change in EPS in the run-up to the implementation of the policy,

8. The mechanism behind this effect is that the ability of an industry in a leading country to innovate is a relevant driver of productivity growth in the same industry across countries thanks to the technological spillovers within the industry.

9. Countries for which data are available for the whole period (1990 - 2010) are: Denmark, Finland, France, United Kingdom, Italy, Japan, the Netherlands, Norway, Portugal, Spain, Sweden, and the United States.. Shorter time periods are available for Canada (1990 - 2009), Germany (1991 - 2010), Belgium (1991 2004), Australia (1993 - 2010), Hungary (1995 - 2010), Greece (1995 - 2007), Austria (2001 - 2010). 
followed by a re-bound effect in the medium term. The coefficient is significant and negative. The overall cumulated effect of the lag and lead factors is not significantly different from zero, suggesting that the two effects balance out. ${ }^{10}$

Table 1. Macro level: Main estimation results

\begin{tabular}{|c|c|c|c|c|c|c|}
\hline $\begin{array}{c}\text { Dependent } \\
\text { variable: MFP } \\
\text { growth } \\
\end{array}$ & 1 & 2 & 3 & 4 & 5 & 6 \\
\hline & Baseline & $\begin{array}{c}\text { Baseline + } \\
\text { controls }\end{array}$ & Baseline & $\begin{array}{c}\text { Baseline + } \\
\text { controls }\end{array}$ & Baseline & $\begin{array}{c}\text { Baseline + } \\
\text { controls }\end{array}$ \\
\hline \multirow[t]{2}{*}{$\begin{array}{l}\text { Growth of MFP of } \\
\text { technology leader }\end{array}$} & $0.355 * * *$ & $0.348^{* * *}$ & $0.351 * * *$ & $0.346^{* * *}$ & $0.273 * * *$ & $0.319 * * *$ \\
\hline & $(0.0663)$ & $(0.0700)$ & $(0.0676)$ & $(0.0697)$ & $(0.0682)$ & $(0.0774)$ \\
\hline \multirow[t]{2}{*}{$\begin{array}{l}\text { Technology gap in } \\
\text { MFP levels (t-1) }\end{array}$} & $0.115 * * *$ & $0.0982 * * *$ & $0.112 * * *$ & $0.0969 * * *$ & $0.102 * * *$ & $0.0866 * * *$ \\
\hline & $(0.0195)$ & $(0.0202)$ & $(0.0210)$ & $(0.0203)$ & $(0.0209)$ & $(0.0224)$ \\
\hline \multirow[t]{2}{*}{$\begin{array}{l}\text { EPS tightening } \\
\text { (MA lags) }\end{array}$} & 0.0146 & $0.0151 *$ & 0.00271 & 0.00766 & $0.0183 *$ & $0.0192 * *$ \\
\hline & $(0.00876)$ & $(0.00768)$ & $(0.0190)$ & $(0.0187)$ & $(0.00904)$ & $(0.00891)$ \\
\hline \multirow[t]{2}{*}{$\begin{array}{l}\text { Effect of gap on } \\
\text { EPS tightening } \\
\text { (MA lags) }\end{array}$} & & & 0.0339 & 0.0218 & & \\
\hline & & & $(0.0616)$ & $(0.0551)$ & & \\
\hline \multirow[t]{2}{*}{$\begin{array}{l}\text { EPS tightening } \\
\text { (MA leads) }\end{array}$} & & & & & $-0.0133 * *$ & $-0.0109 *$ \\
\hline & & & & & $(0.00473)$ & $(0.00599)$ \\
\hline $\begin{array}{l}\text { Country fixed } \\
\text { effects }\end{array}$ & Yes & Yes & Yes & Yes & Yes & Yes \\
\hline $\mathrm{N}$ & 277 & 277 & 277 & 277 & 261 & 261 \\
\hline Adj. R-squared & 0.691 & 0.704 & 0.691 & 0.703 & 0.722 & 0.735 \\
\hline
\end{tabular}

Note: Robust standard errors in parentheses; ${ }^{* *}$ denotes statistical significance at the $1 \%$ level, ${ }^{* *}$ significance at $5 \%$ level, * significance at $10 \%$ level.

(MA): denotes the moving average of the EPS change over three-years-lags/leads.

Baseline specification includes the following controls: Output gap, growth rate of average hours worked per employee, time trend, dummies for crisis years 2007 and 2008. Baseline + controls specification includes cyclically adjusted general government primary balance as percent of potential GDP, trade openness, industry share in \% of total activity, business expenditure on R\&D as \% of GDP, employment protection legislation, product market regulation and the change in real oil price.

\subsubsection{Magnitude of the effect}

26. The effects of changes in EPS on productivity are not found to depend on the initial level nor growth rate of MFP. The example of Italy is taken to illustrate their magnitude. The marginal effect of an average change in EPS (0.12) is roughly equivalent to a situation in which if Italy would adopt, for one year, a speed of environmental tightening as fast as it was seen on average in Denmark over the past two decades (Figure 3). Starting from the productivity growth in Italy in 2010 (last year in the sample), Italy would see a decline in productivity growth of 0.08 percentage points one year before a tightening in EPS is implemented - but when the upcoming EPS tightening is already likely to be publicly known. In the three years after the policy change, MFP growth would rebound to $1.22 \%$ as compared to the $1.17 \%$ in the

10. The null hypothesis of the Wald test (the sum of the coefficients is equal to zero) cannot be rejected (pvalue: 0.3829 ). 
baseline scenario without policy change. Thereafter, the effect would be zero. Overall, the positive rebound effect cancels out the initial negative effect implying that productivity levels are not affected in the long run.

\section{Figure 3. Simulated effects on macro level productivity growth}

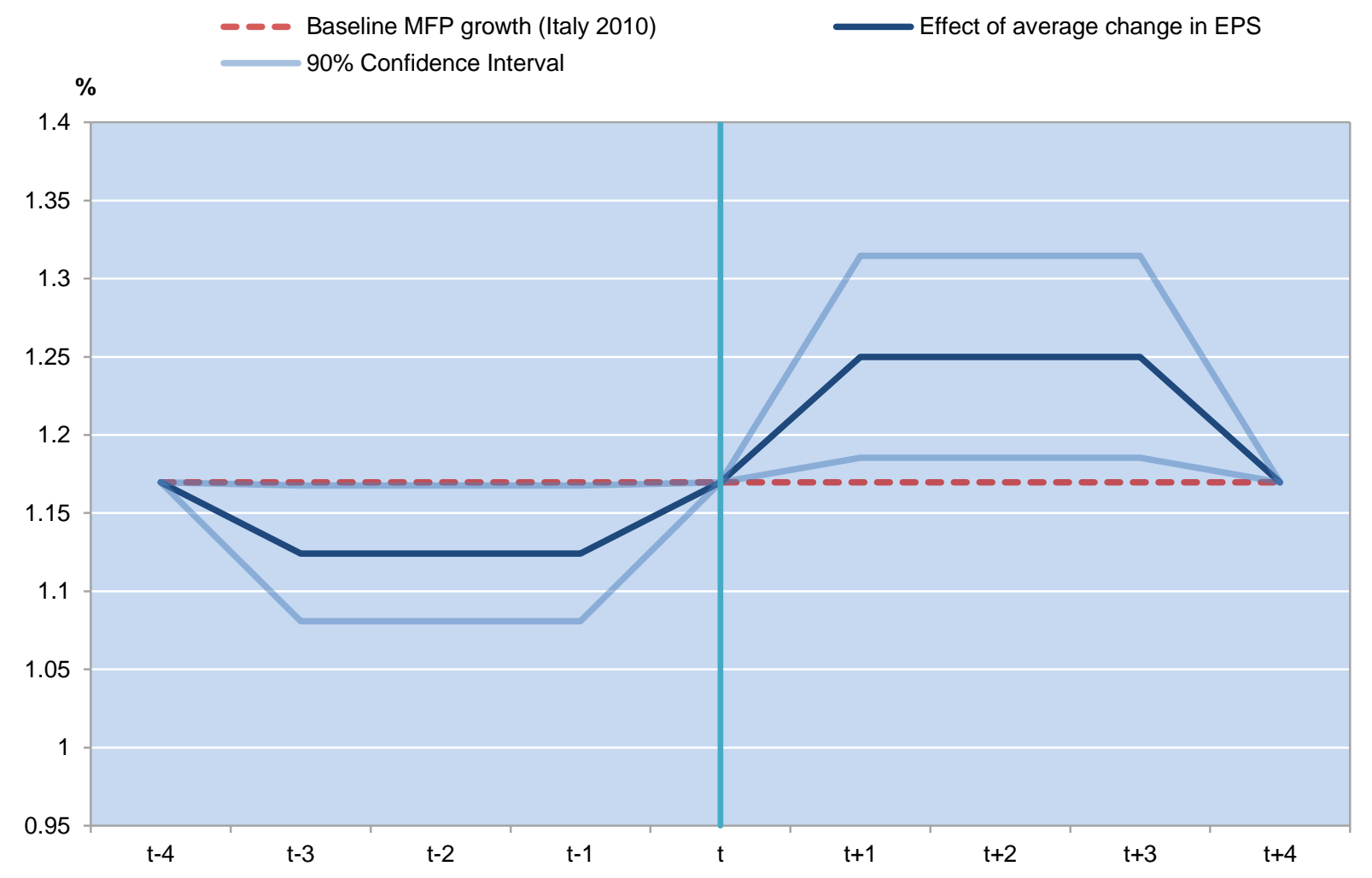

Note: The absolute level of effect (in terms of percentage points of annual MFP growth) will be the same for all countries, regardless of their productivity growth. $95 \%$ confidence intervals are reported.

Source: Authors' calculation.

\subsection{Industry analysis}

27. The industry-level analysis is based on the same reduced-form model of MFP growth as at the macro level:

$$
\begin{gathered}
\Delta \ln M F P_{c i t}=\propto_{1}+\sum_{j=1}^{n} \propto_{2 j}\left(E D_{i 1987} \Delta E P S_{c t-j}\right)+\sum_{j=1}^{n} \propto_{3 j_{i t-j}} g a p_{c i t-1}\left(E D_{i 1987} \Delta E P S_{c t-j}\right) \\
+\propto_{4} g a p_{c i t-1}+\propto_{5} \Delta \ln \widetilde{M F P}_{i t}+\boldsymbol{x}_{c i t} \gamma+\eta_{t}+\delta_{c i}+\epsilon_{c i t}
\end{gathered}
$$

where:

- $\quad \Delta \ln M F P$ is the multifactor productivity growth for each combination of country c and industry $\mathrm{i}$. 
- $\quad \triangle E P S$ is the change of the country EPS and captures the tightening of country's environmental policy stringency. As mentioned above a change in a country's EPS is interacted with pre-sample industry environmental dependence $(E D) .{ }^{11}$

- The third term allows for nonlinear effects of the policy as a function of the technological gap, defined as the distance to the country-industry frontier gap $=\ln \left(\frac{\overline{\mathrm{MFP}}_{1}}{\mathrm{MFP}_{\mathrm{ci}}}\right)$.

- The fourth term is the distance to the productivity frontier which allow for technological catch-up effects.

- The fifth term is the growth in the leader MFP and represents the technological pass-through.

- $\boldsymbol{x}_{\boldsymbol{c i t}}$ is a vector of additional country and industry controls, which varies across the econometric specifications considered (see section "Results").

- Finally, aside from the above, the specification controls for a common time trend, the financial crisis, output gap and country-industry fixed effects $\left(\delta_{c i}\right)$ or, alternatively, country and industry fixed effect are included separately: $\delta_{c}$ and $\delta_{i}$.

\subsubsection{Data}

\section{Industry productivity data}

28. The index of multifactor productivity is constructed using the OECD Structural Analysis database (STAN) and the Productivity Database By industry (PDBi). It is calculated as the residual from a $\log$ Cobb-Douglas production function, with the labour factor intensity equal to $1 / 3$ across countries and time:

$$
\ln M F P_{i c t}=\ln \text { ValueAdded }_{\text {cit }}-\propto \ln L_{c i t}-(1-\propto) \ln K_{c i t}
$$

29. MFP growth is estimated as a two-year moving average for a panel of 17 OECD countries and 10 manufacturing sectors over the time period 1990-2009. ${ }^{12}$ The technological frontier at the industry level as well as the distance to frontier (DTF), are also constructed following Bas et al. (2013). ${ }^{13}$

11. Industry environmental dependence is measured as an index of industry pollution intensity (see section 6.2.2).

12. The countries included are Australia, Austria, Belgium, Canada, Denmark, Finland, France, Germany, Greece, Italy, Japan, the Netherlands, Norway, Spain, Sweden, the United Kingdom and the United States. The manufacturing industries covered in the sample are food, beverages and tobacco (ISIC Rev.3.1 code 1516), textiles and footwear (1719), wood (2000), pulp, paper and printing (2122), chemical, rubber, plastics and fuel products (2325), other non-metallic mineral products (2600), basic metals and fabricated metal products (2728), machinery and equipment (2933), transport equipment (3435) and manufacturing n.e.c. and recycling (3637).

13. See Bourlès et al. (2013) for a similar approach, while Bas et al. (2013) also include a discussion of the data. 


\section{Industry Environmental Dependence}

30. The environmental dependence variable is an index of industry pollution intensity and is used to proxy for industries' exposure to environmental regulation. It is constructed for each industry using the IPPS Pollution Intensity and Abatement Cost World Bank dataset which collects data for the US manufacturing sector in 1987. The rationale for choosing the United States as country of reference is twofold. Firstly, the IPPS WB dataset gives a complete and comprehensive cross-section information set, which is not available for other countries, in particular so far back in time. Secondly, it can be considered a good proxy for the pre-sample status quo of the OECD countries included in the analysis, both in terms of technology available and environmental policies.

31. Industries are ranked based on pollution intensity (relative to value added) on seven pollutant categories (two water pollutants, four air pollutants, one toxic substance). The "environmental dependence" is then the simple average of these seven scores, and it can take values from zero (least polluting industry) to 1 (most polluting industry). Figure 4 reports the ED index by sector.

Figure 4. Environmental dependence by industry

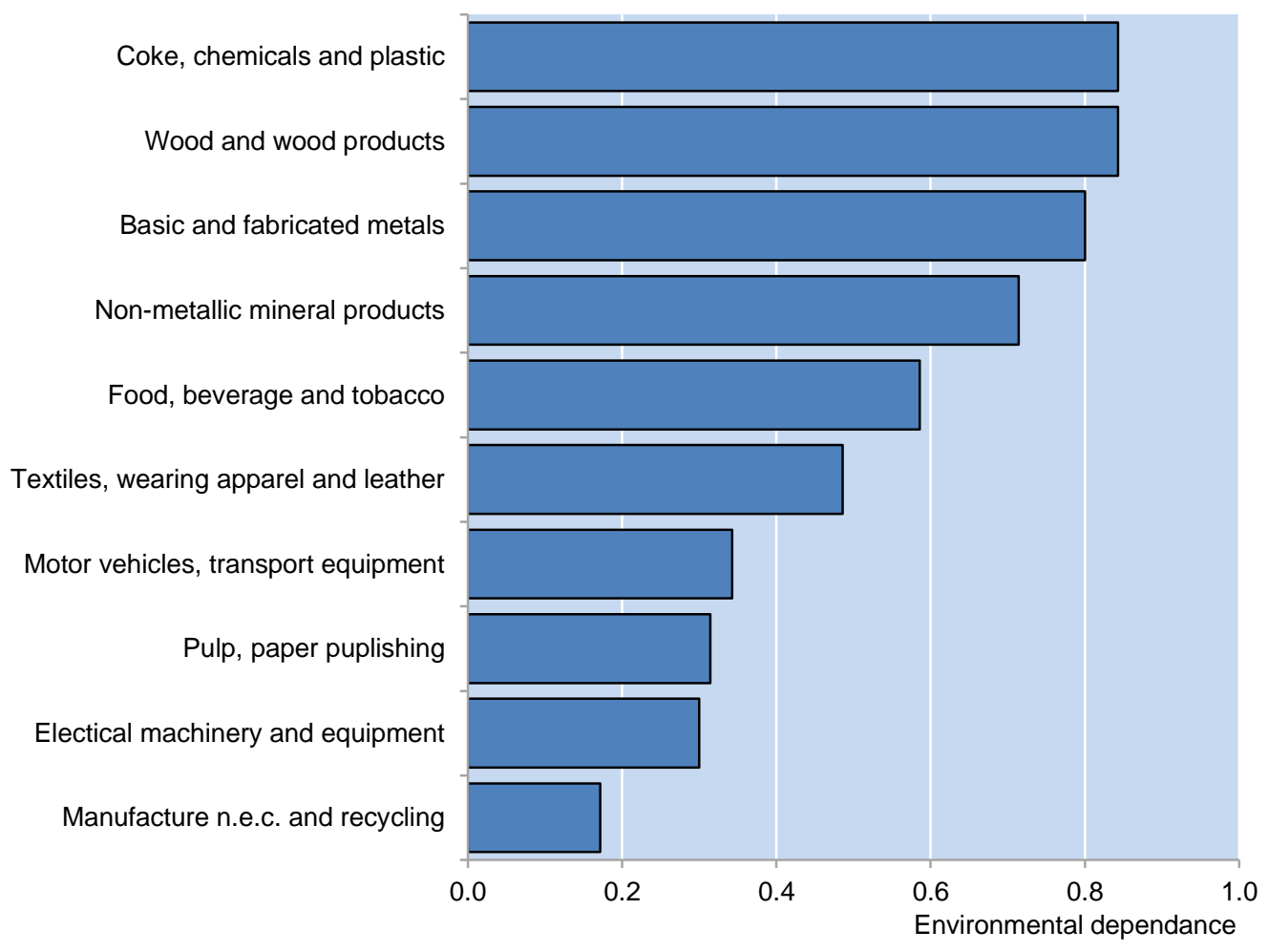

Source: Authors calculation based on WB pollution intensity data on US manufacturing sectors for 1987.

32. Such an index has both advantages and disadvantages. Pre-sample pollution intensities and the reference to one single country, the United States, helps avoid measurement issues as part of the effect of the EPS on productivity is through the change in sector environmental dependence. Moreover, as argued above, US industries are likely to adequately represent available technologies of the developed countries covered in the analysis. Still, using 1987 US values for all the countries could be a source of measurement 
error and attenuation bias, for instance, if industries' environmental dependence in individual countries differs significantly from that of the US (or if environmental dependence in-sample is also different than that in 1987). Using the relative ranking of sectors, rather than absolute values, for construction of the environmental dependence measure is likely to make this problem smaller.

33. In light of these potential limitations of the ED variable, two additional tests were performed. The main specification was estimated excluding US from the sample, and an alternative interaction term, defined as the industry energy dependence, is used to represent the exposure to environmental regulation. This variable is defined as the average ratio of energy input over the value added for each industry across countries and time (1990-2009), based on OECD STAN Input/Output tables. Sectors rankings along environmental dependence do not change significantly across the two different definitions and the results are invariant to both dropping the US and changing the definition of ED.

34. Figures 5 and 6 present the variability of changes in industry EPS (defined as EPS*ED, where environmental dependence is based on 1987 pollution intensities in the US) over time, both from a country and industry perspective.

Figure 5. Average industry EPS by country in selected years

1995, 2002, 2008

$\square 1995 \quad \square 2002 \quad \square 2008$

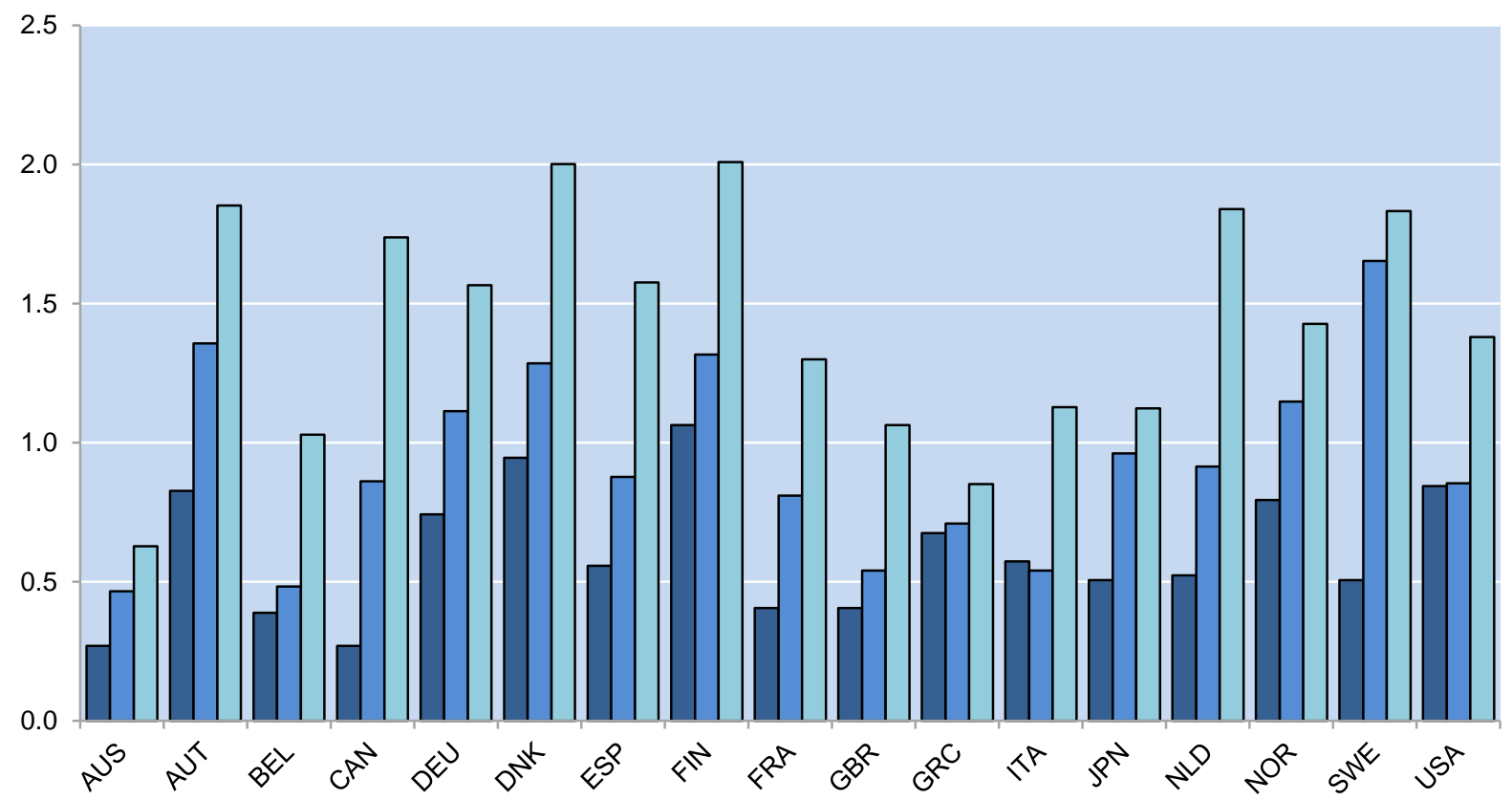

Note: Variability in industry EPS by country in three selected years: 1995, 2002 and 2008. Industry EPS is defined as the interaction between the country EPS and the industry ED index, where environmental dependence is constructed using 1987 pollution intensities in the US.

Source: Authors' calculations. 
Figure 6. Average industry EPS by sector in selected years

1995, 2002, 2008

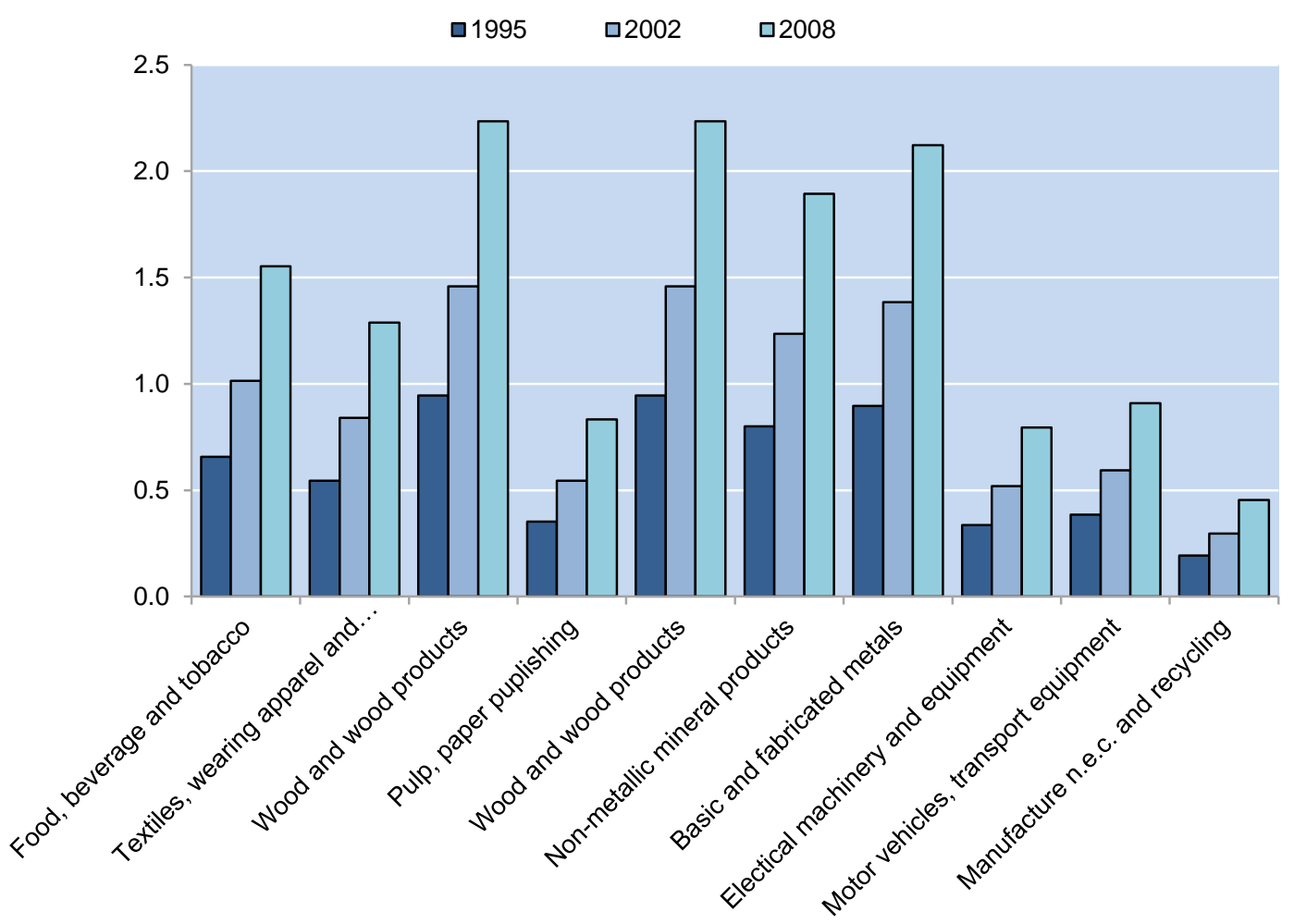

Note: Variability in industry EPS by industry in three selected years: 1995, 2002 and 2008. Industry EPS is defined as the interaction between the country EPS and the industry ED index, where environmental dependence is constructed using 1987 pollution intensities in the US.

Source: Authors' calculations.

\subsubsection{Main Results}

35. The findings highlight that a tightening in environmental policy stringency has a positive shortterm effect on industry-level productivity growth, in countries where the industry is close to the global technological frontier. This effect diminishes as the distance to the global technology frontier increases and becomes insignificant far from the frontier. ${ }^{14}$

36. Table 2 reports the results for several specifications, with country-industry fixed effects (column 1), with separate country and industry effects (column 2), with controls for additional regulations (employment protection legislation, product market regulation and the country's degree of capital account openness) (column 3 and 4) and industry-specific time-varying characteristics (trade openness, R\&D expenditures - as in the macro-level analysis - and real oil price) (column 5 and 6). Finally columns 7 and 8 consider the full set of controls. Frontier observations are excluded from the sample in all the specifications.

14. Note that while the industry-level analysis is based on the timespan 1990-2009, the results hold over the 2000-2009 sub-sample, i.e. a time horizon similar to that of the firm-level analysis (see below). 
Table 2. Industry level: Main estimation results

\begin{tabular}{|c|c|c|c|c|c|c|c|c|}
\hline Column1 & 1 & 2 & 3 & 4 & 5 & 6 & 7 & 8 \\
\hline & Baseline & Baseline & $\begin{array}{l}\text { Baseline + } \\
\text { Regulation }\end{array}$ & $\begin{array}{l}\text { Baseline + } \\
\text { Regulation }\end{array}$ & $\begin{array}{c}\text { Baseline }+ \\
\text { Country/ind } \\
\text { controls }\end{array}$ & $\begin{array}{c}\text { Baseline }+ \\
\text { Country/ind } \\
\text { controls }\end{array}$ & $\begin{array}{l}\text { Full set } \\
\text { of } \\
\text { controls }\end{array}$ & $\begin{array}{l}\text { Full set of } \\
\text { controls }\end{array}$ \\
\hline \multirow[t]{2}{*}{ Leader MFP growth } & $0.151 * * *$ & $0.129 * * *$ & $0.149 * * *$ & $0.128 * * *$ & $0.129 * * *$ & $0.107 * * *$ & $0.126 * * *$ & $0.105 * * *$ \\
\hline & $(0.0276)$ & $(0.0283)$ & $(0.0273)$ & $(0.0283)$ & $(0.0289)$ & $(0.0294)$ & $(0.0286)$ & $(0.0295)$ \\
\hline \multirow[t]{2}{*}{$\begin{array}{l}\text { Distance to frontier } \\
\text { (lagged) }\end{array}$} & $0.172 * * *$ & $0.0921 * * *$ & $0.168 * * *$ & $0.0898 * * *$ & $0.170 * * *$ & $0.0915 * * *$ & $0.166^{* * *}$ & $0.0892 * * *$ \\
\hline & $(0.0264)$ & $(0.0133)$ & $(0.0252)$ & $(0.0128)$ & $(0.0259)$ & $(0.0127)$ & $(0.0245)$ & $(0.0122)$ \\
\hline \multirow[t]{2}{*}{ EPS tightening (MA) } & $0.147 * * *$ & $0.130 * * *$ & $0.150 * * *$ & $0.134 * * *$ & $0.151 * * *$ & $0.140 * * *$ & $0.151 * * *$ & $0.143 * * *$ \\
\hline & $(0.0371)$ & $(0.0278)$ & $(0.0375)$ & $(0.0283)$ & $(0.0327)$ & $(0.024)$ & $(0.0334)$ & $(0.025)$ \\
\hline \multirow[t]{2}{*}{$\begin{array}{l}\text { Effect of gap on EPS } \\
\text { tightening (MA) }\end{array}$} & $-0.212 * *$ & $-0.165^{* *}$ & $-0.216^{* *}$ & $-0.170 * *$ & $-0.201 * *$ & $-0.166 * * *$ & $-0.203 * *$ & $-0.170 * * *$ \\
\hline & $(0.101)$ & $(0.0775)$ & $(0.101)$ & $(0.0773)$ & $(0.0797)$ & $(0.0553)$ & $(0.0793)$ & $(0.0555)$ \\
\hline \multicolumn{9}{|l|}{ Fixed effects } \\
\hline Country*Industry & Yes & No & Yes & No & Yes & No & Yes & No \\
\hline Country & No & Yes & No & Yes & No & Yes & No & Yes \\
\hline Industry & No & Yes & No & Yes & No & Yes & No & Yes \\
\hline $\mathrm{N}$ & 2084 & 2084 & 2084 & 2084 & 1944 & 1944 & 1944 & 1944 \\
\hline adj. R2 & 0.12 & 0.169 & 0.123 & 0.174 & 0.123 & 0.188 & 0.125 & 0.191 \\
\hline
\end{tabular}

Note: Robust standard errors in parentheses and they are clustered at country-industry level; ${ }^{* *}$ denotes statistical significance at the $1 \%$ level, ${ }^{* *}$ significance at $5 \%$ level, ${ }^{*}$ significance at $10 \%$ level.

(MA): denotes the moving average of the EPS change over three-years-lags.

Baseline specification includes the following controls: output gap, dummy for crisis and year trend. Baseline + Regulation includes: employment protection legislation (OECD EPL), product market regulation (OECD PMR) and country's degree of capital account openness (Chinn-Ito Index). Baseline + Country/ind. includes industry-specific time-varying controls, such as trade openness, R\&D expenditures, and real oil price.

37. In line with previous literature, the coefficient on the MFP growth of the leader is positive indicating a pass-through effect from the leader to the lagging industries. Moreover, there is evidence of catch-up effects (positive and significant coefficient of the gap), namely country-industry pairs that are farther from the technology frontier tend to grow faster.

38. In terms of the controls, capital account openness, $R \& D$ intensity and output gap are found to be significantly and positively associated with productivity growth, as expected. The dummy for the financial crisis of 2007-09 is negative and significant and the trend captures the slowdown of MFP growth in advanced economies (Gordon, 2012). Finally, product market regulation has a negative effect on productivity growth, as expected.

\subsubsection{Marginal Effects}

39. Turning to the main variable of interest, the estimated marginal effect of a tightening in environmental policy on industry productivity growth depends on the technological advancement of the country-industry pair with respect to the global frontier:

$$
\frac{\partial \Delta \ln M F P_{c i t}}{\partial\left(E D_{i 1987} \Delta E P S_{c t-1}\right)}=\propto_{2 j}+\propto_{3} g a p_{c i t}
$$


40. To check for the magnitude and significance of the estimated marginal effect we calculate the overall marginal effect for different values of the distance to frontier (Figure 7), over the observed DTF range, and the corresponding confidence intervals (Figure 8). ${ }^{15}$

Figure 7. Distribution of industries with respect to the distance to the frontier

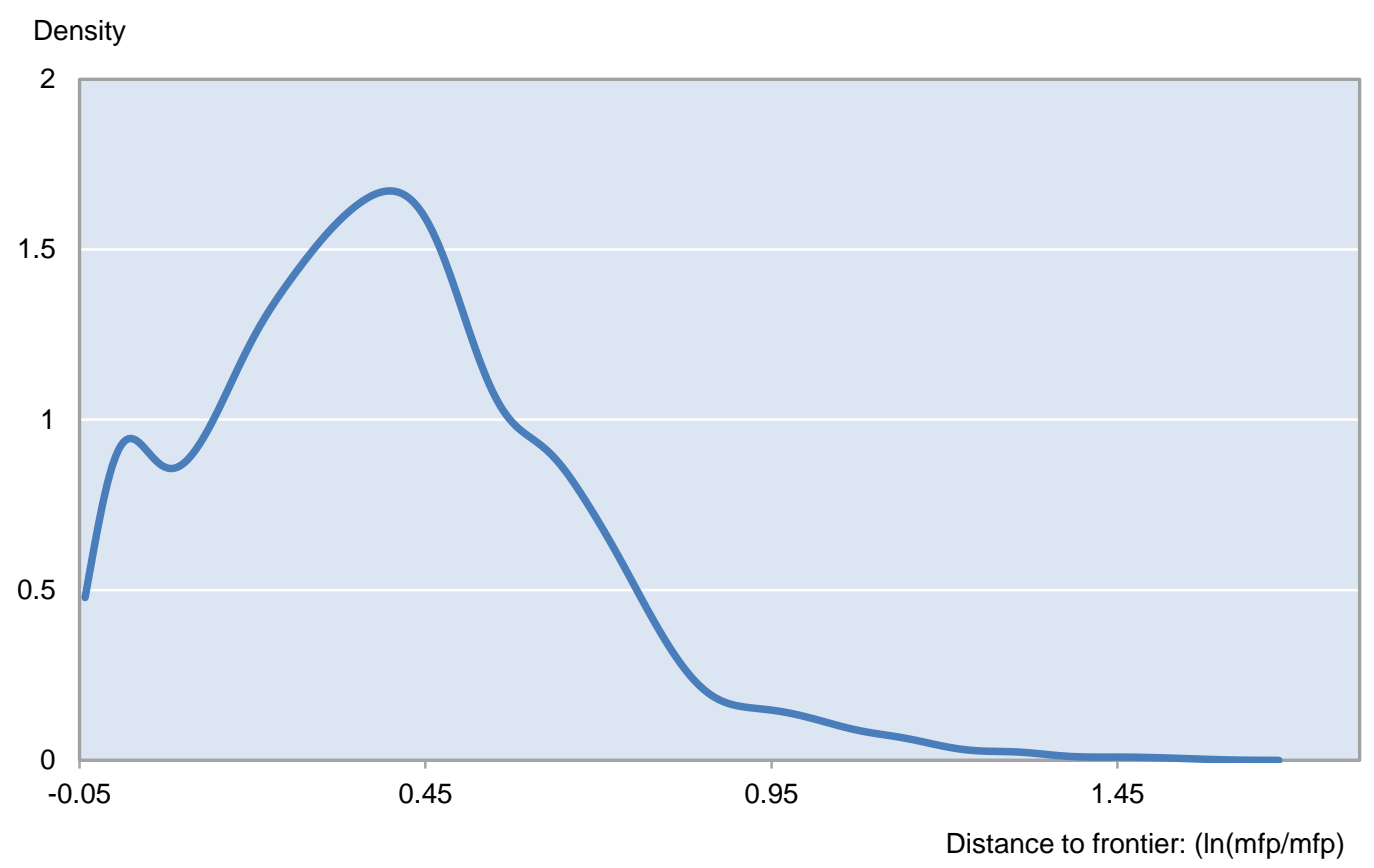

Note: Kernel density estimates of the distribution of country-industry pairs with respect to the distance to the industry technology frontier.

41. The short-run marginal effect of tightening in industry-EPS on industry level MFP growth is positive throughout most of the distance to frontier, leading overall to a permanently higher MFP level (Figure 8). This effect fades away only for countries far from the frontier.

42. This heterogeneous effect suggests that in each industry the most productive countries benefit most, in terms of productivity growth. This may be due to the fact that in these countries firms have access to top technologies and are most capable to adapt to the new regulations, for example by improving production technology. They may also have the best access to financial markets, networks etc., hence being better suited to accommodating the policy change. Such a channel would in principle support the Porter Hypothesis. Under this hypothesis well-designed environmental policies can create incentives for adjustment, whereby the gains can potentially outweigh the costs leading to efficiency gains and higher productivity.

43. However, this effect could also be due to a reallocation effect, with productivity gains due to a more rapid axing of less productive firms or outsourcing of less-productive activities as a result of additional costs imposed by environmental policies. This reallocation and entry-exit effect is not identifiable at the industry level, but would likely inflate the observed productivity gains.

15. Given the skewed distribution of the distance to frontier, the right-hand extreme values are dropped (10\% of the distribution). 
Figure 8. Marginal effect of an EPS tightening by the distance to frontier - industry level

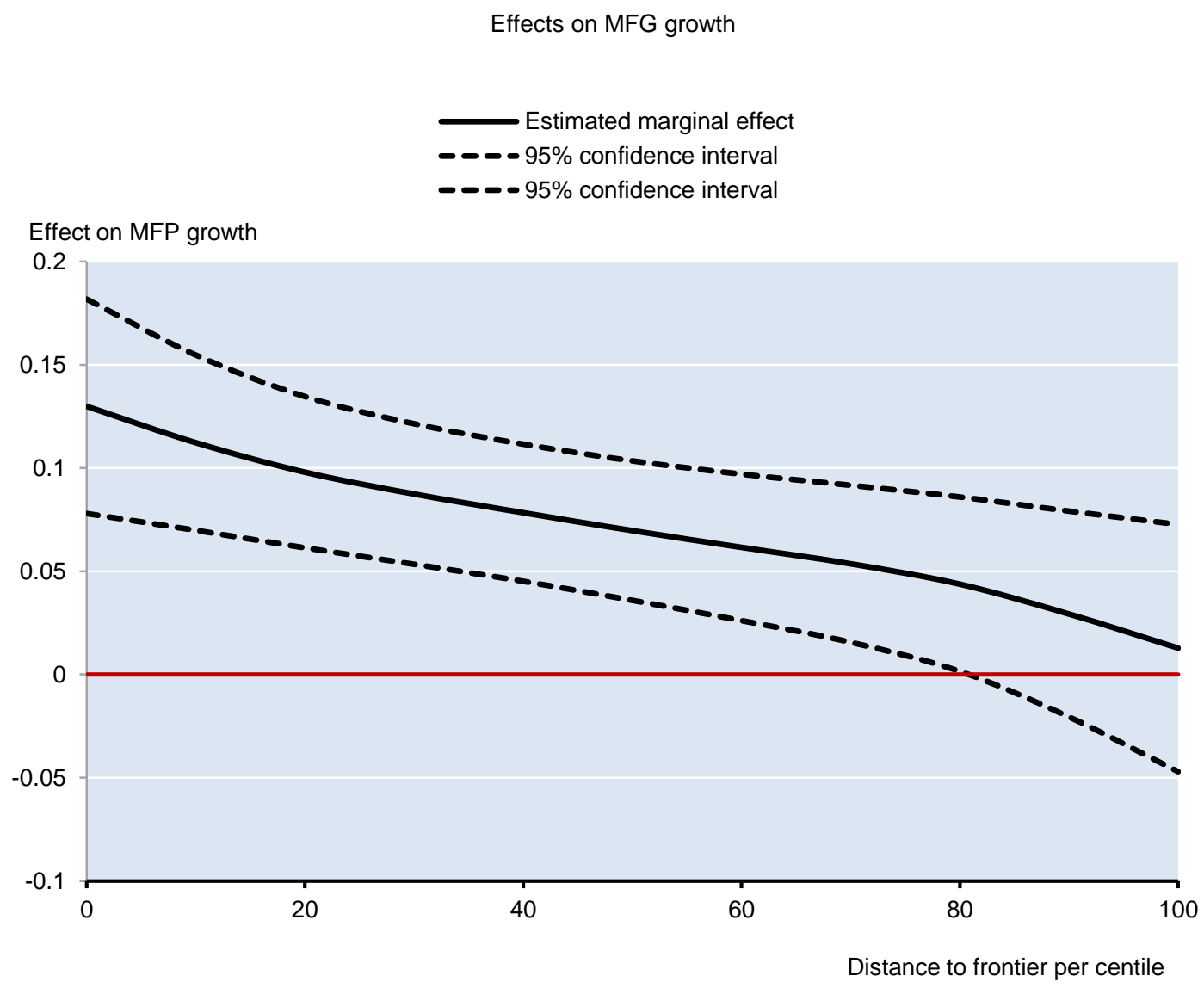

44. To explore the heterogeneous magnitude of the marginal effect according to the environmental dependence of the industry and the distance to frontier, Figure 9 reports expected effects of an average tightening in the EPS (0.12 points) along two dimensions using country examples and 2005 as year of reference.

45. Taking the United States as an example: if the country tighten its EPS by twice its average tightening over the sample (from an average of 0.1 to 0.22 , equal to the average tightening in Denmark), the MFP growth of the highly-polluting coke, chemical and plastic sector, would be expected to increase by almost 0.5 percentage points annually for a three-year period (top left panel in Figure 9). By contrast, for a country-industry pair distant from the frontier, such as Australia in the same sector, the effect is insignificant (bottom left panel in Figure 9). For the less productive industries, there is no effect (right panels in Figure 9). 
Figure 9. Simulated effects of EPS tightening on industry MFP growth
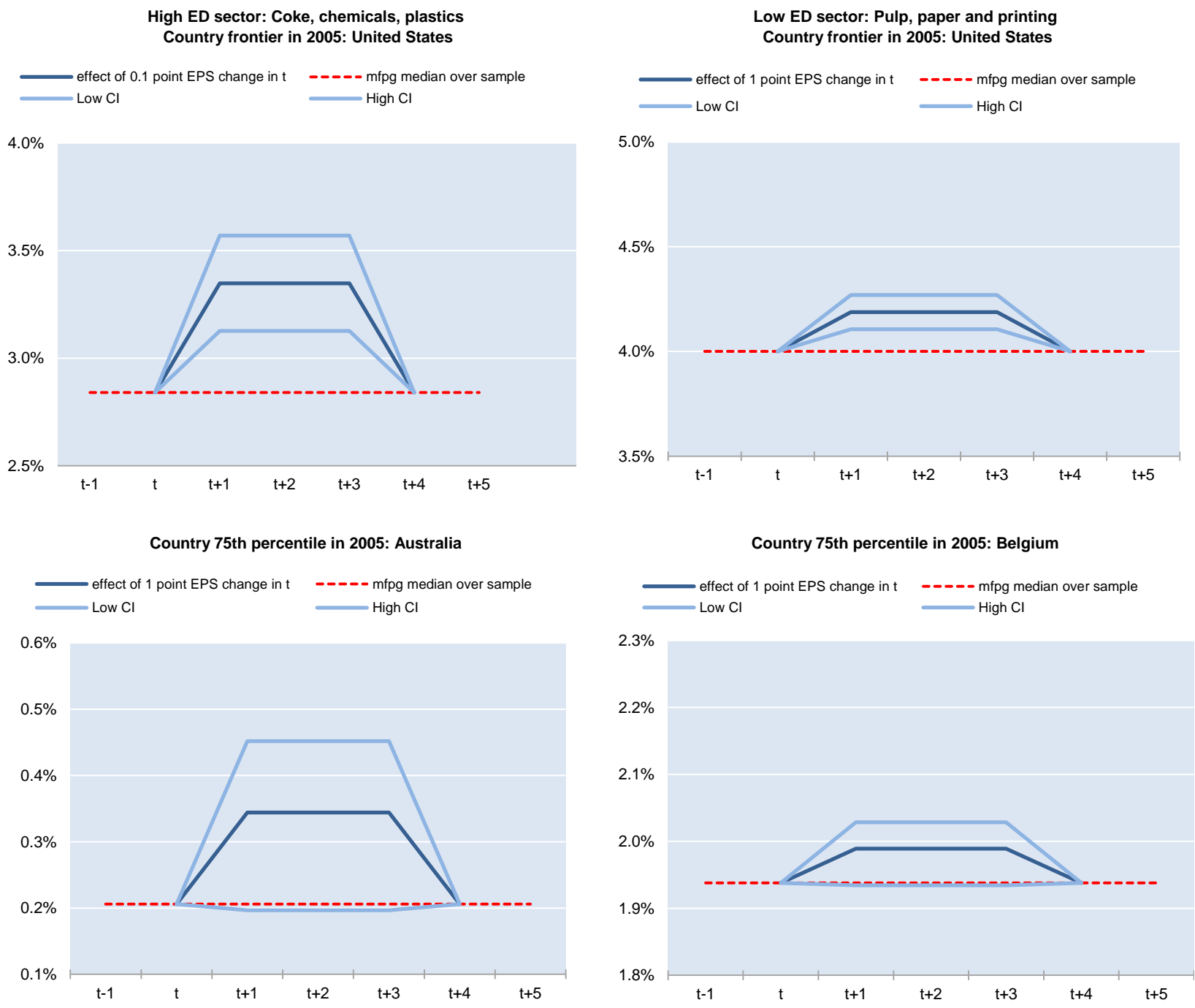

Note: The first column compares the effect of a simulated EPS tightening ( 0.12 , points equal to an average annual tightening) in a high ED sector for a country close to the productivity frontier (top left panel) and for a country at the 75th percentile of the distance to technology frontier (bottom left panel). In the second column evidence for a low ED sector is presented. 95\% confidence intervals are reported.

\subsection{Firm analysis}

46. Following the country and industry analysis, this section seeks to corroborate the industry-level results by looking at the effect of environmental policy stringency (EPS) on firm-level multifactor productivity growth. For this reason, the same model of multi-factor productivity growth is estimated adding firm-level controls. 


\subsubsection{Methodology and data}

47. As in the industry model, the overall effect of EPS depends on the individual industries pollution intensity and the distance from the technological frontier. In this case the frontier is defined as the average MFP of the 5\% most productive firms in industry $i$ in year $t$, across countries. Additional firm-level controls $\left(\mathbf{z}_{\text {cift }}\right)$ are considered with respect to the industry analysis: ${ }^{16}$

$$
\begin{gathered}
\Delta \ln M F P_{\text {cift }}=\propto_{1}+\sum_{j=1}^{n} \propto_{2 j}\left(E D_{i 1987} \Delta E P S_{c t-j}\right)+\sum_{j=1}^{n} \propto_{3 j}{ }_{i t-j} \operatorname{gap}_{c i f t-1}\left(E D_{i 1987} \Delta E P S_{c t-j}\right) \\
+\propto_{4} \text { gap }_{\text {cift }-1}+\propto_{5} \Delta \ln \widetilde{M F P}_{i f t}+\boldsymbol{x}_{\text {cit }} \gamma+\boldsymbol{z}_{\text {cift }} \omega+\eta_{t}+\delta_{c}+\delta_{i}+\epsilon_{c i f t}
\end{gathered}
$$

where $f$ indexes firms.

\section{Firm productivity data}

48. MFP is constructed using the ORBIS database following the approach of Woodridge (2009). ${ }^{17}$ The panel consists of 11 OECD countries and 22 manufacturing sectors over the time period 2000-2009. ${ }^{18}$ The selection is based on the number of observations, stability of the number of observations over time, and the representativeness of the firm size distribution in the population of interest (based on national business registries, Gal, 2013).

\section{Environmental dependence and 2-digit industry EPS}

49. Consistent with the industry approach, the EPS is interacted with industry environmental dependence in order to account for the heterogeneous exposure to environmental policy at the industry level. In this case, the environmental dependence variable is constructed at 2-digit level of aggregation to match the MFP data (Figure 11).

16. A detailed description of the variables of interest can be found in the industry methodological section as well as in Appendix 1.

17. The OECD-ORBIS dataset has been developed by Gonnard and Ragoussis (2012) and Gal (2013) on the Bureau Van Dijk (BvD) ORBIS dataset. The data work underlying this note has been executed by the authors before November 2012. MFP figures are built based on Levinsohn and Petrin (2003), Woodridge's production function estimation is a one-step procedure that attempts to solve the capital measurement issue (Ackerberg et al., 2006). See Gal (2013) for a detailed and comprehensive discussion of the construction of the MFP measures.

18. The countries included are: Belgium, Finland, France, Greece, Italy, Japan, Korea, the Netherlands, Spain, Sweden and the United Kingdom. The industry coverage is 2-digit manufacturing (NACE Rev. 1.1 industries 15 to 37 ). 
Figure 10. Environmental dependence by 2-digit industry classification

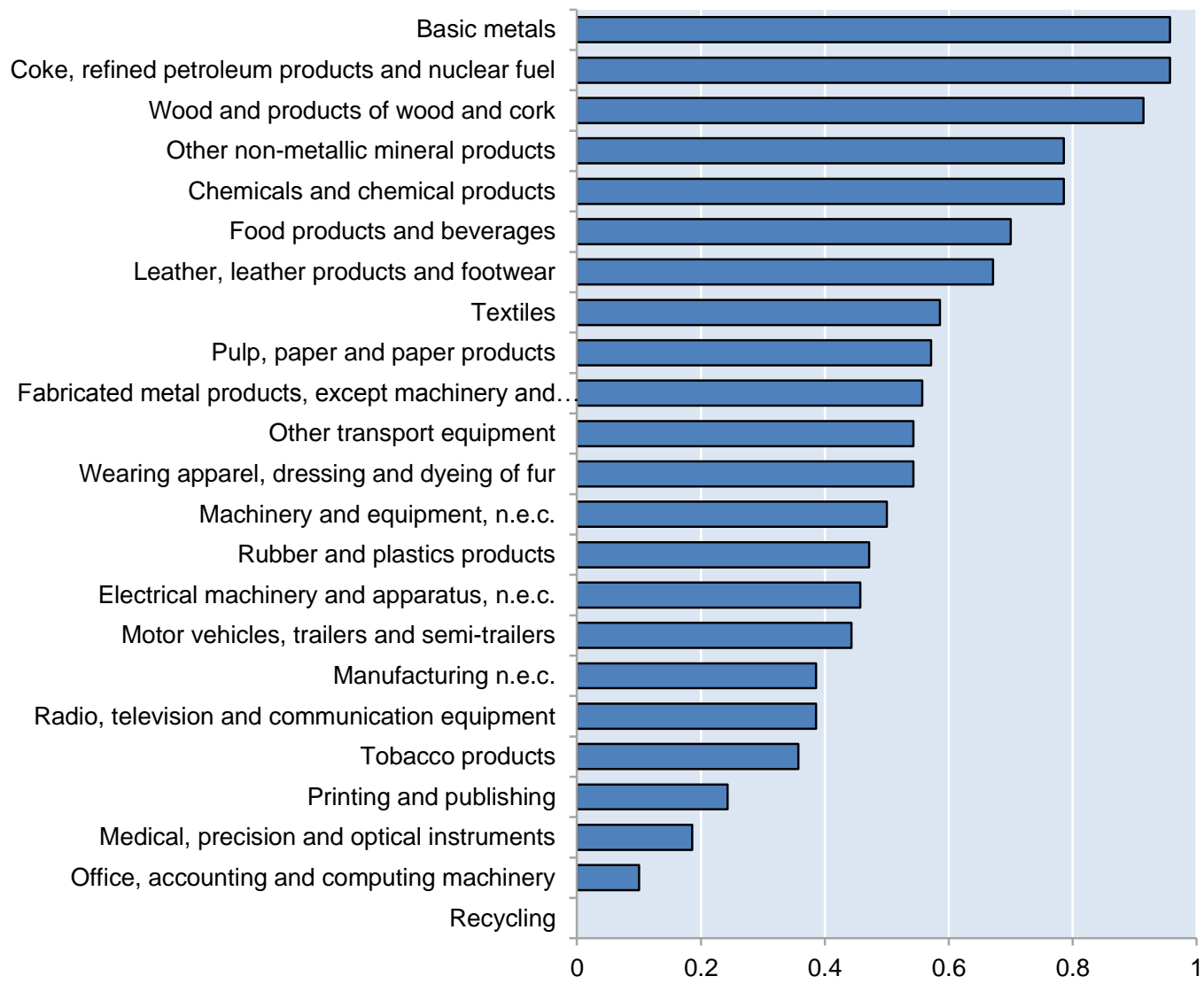

Note: The classification refers to NACE Rev.1.1.

\subsubsection{Main Results}

50. Table 3 reports the results for the main specification. Column (1) includes country and industry dummies to control for time invariant effects. Column (2) shows the specification results when countryindustry dummies are used instead. Columns (3) and (4) control for firm level characteristics, such as size, proxied by the logarithm of employment, and demand shocks, proxied by the logarithm of the firm's turnover, with country and industry and country-industry dummies respectively. Columns (5) and (6) add industry controls (openness and financial development), and country level regulation indicators. Employment protection legislation is interacted with firm's pre-sample number of employees and financial dependence is interacted with firm's pre-sample debt ratio to measure the exposure of each firm to the country-level regulation (Rajan and Zingales, 1998). A detailed description of the controls and their weighting can be found in Table A1.1 in Appendix 1. In line with the analysis at the macro and industry level, a three year moving average of the past changes in the EPS is considered. 
Table 3. Firm level: Main estimation results

\begin{tabular}{|c|c|c|c|c|c|c|}
\hline $\begin{array}{l}\text { Dependent: MFP } \\
\text { growth }\end{array}$ & 1 & 2 & 3 & 4 & 5 & 6 \\
\hline & Baseline & Baseline & $\begin{array}{l}\text { Baseline }+ \\
\text { Firm controls }\end{array}$ & $\begin{array}{l}\text { Baseline }+ \\
\text { Firm controls }\end{array}$ & Full sets of controls & Full sets of controls \\
\hline \multirow[t]{2}{*}{$\begin{array}{l}\text { Growth in MFP in the } \\
\text { technology leader }\end{array}$} & $0.0782 * * *$ & $0.103 * * *$ & $0.0987 * * *$ & $0.145 * * *$ & $0.139 * * *$ & $0.179 * * *$ \\
\hline & $(0.0260)$ & $(0.0245)$ & $(0.0291)$ & $(0.0258)$ & $(0.0167)$ & $(0.0131)$ \\
\hline \multirow[t]{2}{*}{ Gap in MFP levels (t-1) } & $0.175 * * *$ & $0.222 * * *$ & $0.208 * * *$ & $0.293 * * *$ & $0.222 * * *$ & $0.296 * * *$ \\
\hline & $(0.0142)$ & $(0.00761)$ & $(0.0238)$ & $(0.0128)$ & $(0.0229)$ & $(0.0122)$ \\
\hline \multirow[t]{2}{*}{ EPS tightening (MA) } & $0.219 * * *$ & $0.238 * * *$ & $0.184 * * *$ & $0.180 * *$ & $0.143^{* *}$ & $0.147 * *$ \\
\hline & $(0.0655)$ & $(0.0750)$ & $(0.0642)$ & $(0.0748)$ & $(0.0611)$ & $(0.0715)$ \\
\hline \multirow[t]{2}{*}{$\begin{array}{l}\text { Effect of gap on EPS } \\
\text { tightening (MA) }\end{array}$} & $-0.0850 * * *$ & $-0.0981 * * *$ & $-0.0694 * * *$ & $-0.0748 * * *$ & $-0.0665 * * *$ & $-0.0788 * * *$ \\
\hline & $(0.0221)$ & $(0.0253)$ & $(0.0196)$ & $(0.0223)$ & $(0.0188)$ & $(0.0232)$ \\
\hline \multicolumn{7}{|l|}{ Fixed Effect } \\
\hline Country & Yes & No & Yes & No & Yes & No \\
\hline Industry & Yes & No & Yes & No & Yes & No \\
\hline Country*Industry & No & Yes & No & Yes & No & Yes \\
\hline $\begin{array}{l}\text { Standard errors clustered } \\
\text { at country*industry level }\end{array}$ & Yes & Yes & Yes & Yes & Yes & Yes \\
\hline $\mathrm{N}$ & 647392 & 647392 & 625011 & 625011 & 313071 & 313071 \\
\hline adj. R-squared & 0.091 & 0.114 & 0.102 & 0.138 & 0.099 & 0.131 \\
\hline
\end{tabular}

Note: Robust standard errors in parentheses and they are clustered at country-industry level; ${ }^{* \star *}$ denotes statistical significance at the $1 \%$ level, ${ }^{\star *}$ significance at $5 \%$ level, ${ }^{*}$ significance at $10 \%$ level.

(MA): defined as the moving average of the EPS change over three years (lagged).

Baseline specification includes the following controls: output gap and dummies for crisis. Baseline + Firm controls include: employment and turnover (both lagged). The full set of controls additionally includes: employment protection legislation (OECD EPL), regulatory impact (OECD RI), financial development, trade openness and R\&D expenditures. 
51. A tightening of environmental regulation leads to an increase in the productivity growth only of firms close to the frontier, while decreasing MFP growth for the less productive ones. Figure 12 highlights that only one-tenth of the firms in the sample benefit, in terms of MFP growth, from stringent environmental policies, while one-third of the firms, the less productive ones, are negatively affected. Smaller firms tend to be further away from the productivity frontier (Figure 13). Thus, more stringent environmental policies may be putting smaller firms at a disadvantage as they are less capable to adjust, e.g. due to the limited resources.

\section{Figure 11. Marginal effect of an EPS tightening by distance to frontier - firm level}

Effects on MFP growth

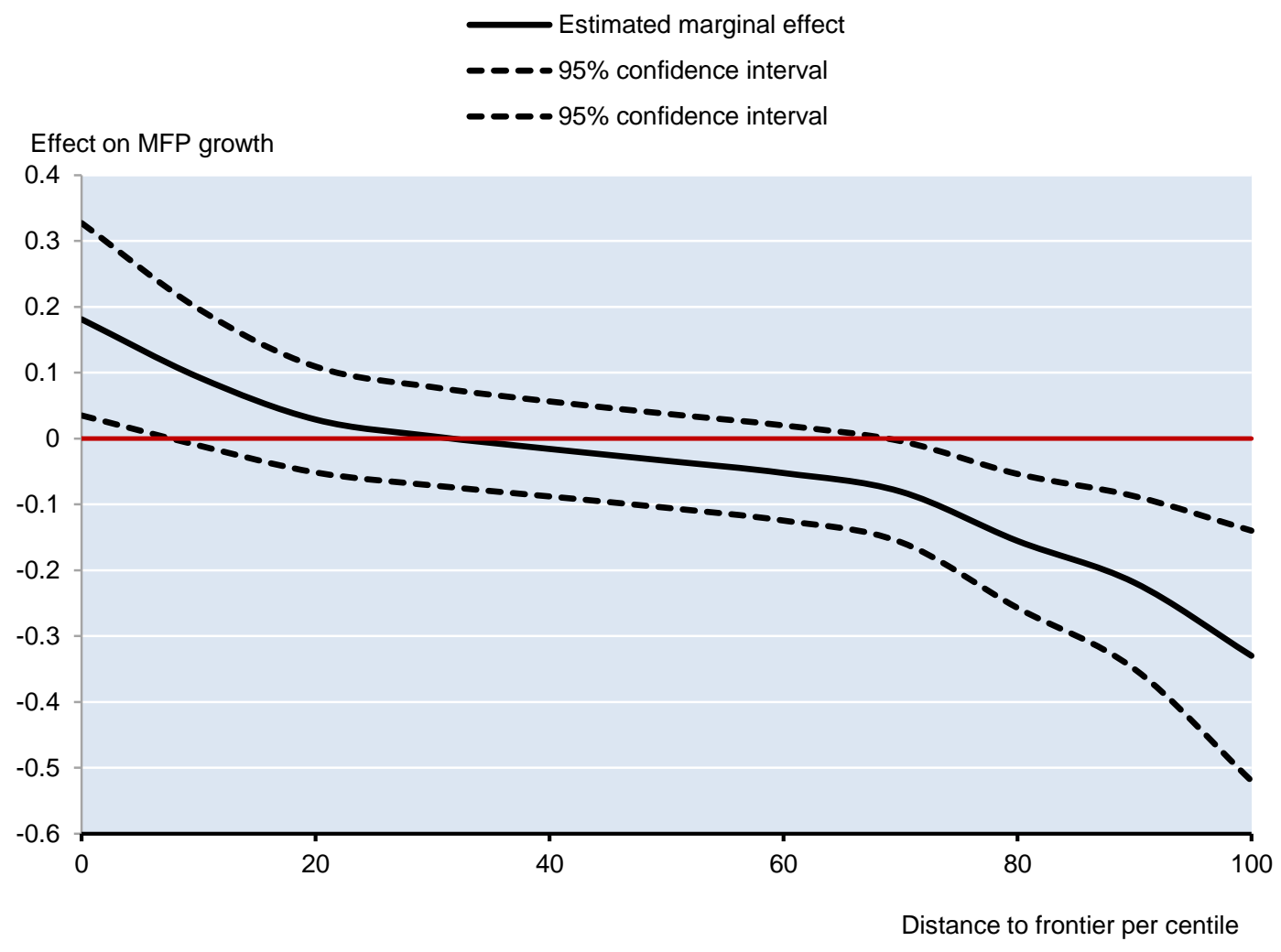


Figure 12. Distribution of distance to the frontier: full sample versus larger firms

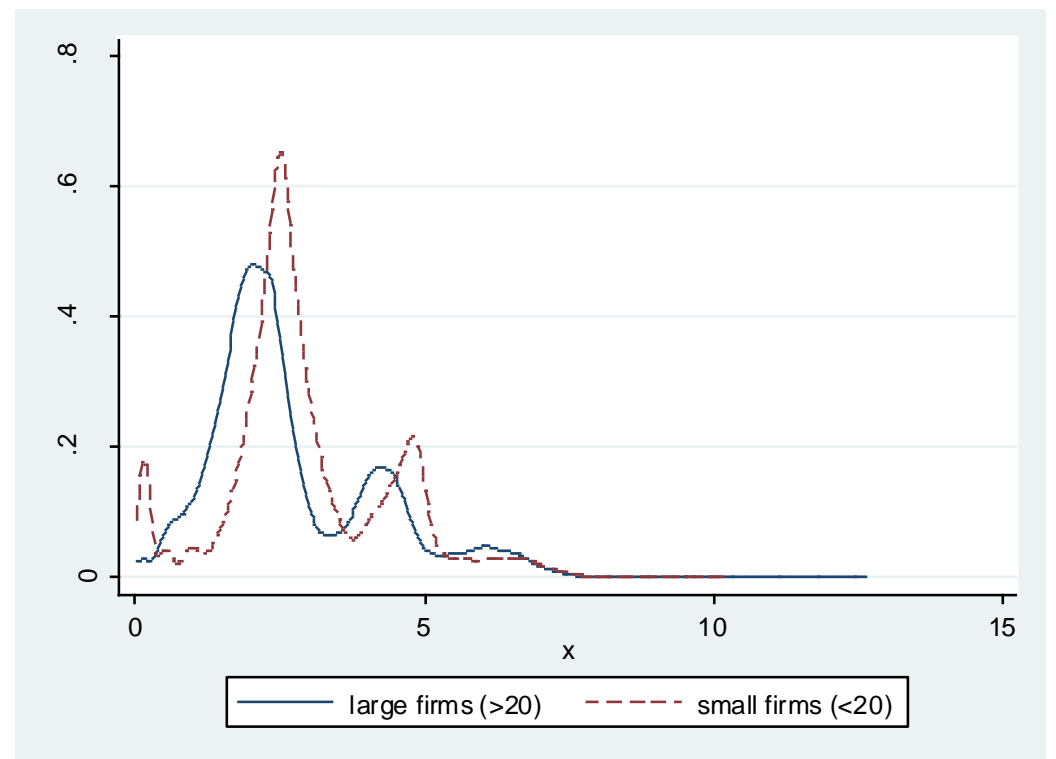

52. The corroboration of the industry results with firm-level evidence provides additional insights on firm-level effects. The significant negative effect for almost one-third of the firm sample is not found for countries furthest from the frontier in the industry level analysis. This combination of results suggests that part of the adjustment, particularly for less technologically advanced firms, may take the form of firm exit. The exit of the least efficient firms would raise overall industry productivity, cancelling out the negative productivity effects observed in surviving less efficient firms. This conjuncture needs to be verified with further analysis with data using firms' demography statistics.

\subsection{Robustness checks}

53. To verify the robustness of the results, two further estimations were performed in each level of analysis (macro, industry and firms). These specifications test the ability of the EPS indicator to (i) represent economy-wide environmental policies and (ii) account for differences in enforcement levels:

- Representativeness of the EPS proxy. The identification strategy is based on the assumption that overall stringency of environmental regulations can be approximated by looking at policy instruments that regulate environmental externalities in selected sectors. Most of the instruments refer to the utilities sector and particularly to fossil-fuel energy generation; hence the measure may be less suitable for countries with a low share of fossil fuel based electricity generation (e.g. Norway). To the extent such countries may score lower than expected on the EPS proxy due to such miss-measurement (e.g. lower stringency of the particular policies captured by our EPS proxy), this may imply erroneous estimates. To check for this, we repeat the estimations excluding countries that have fossil-fuel electricity generation capacity share below $30 \% .{ }^{19}$ The results are not affected, confirming that the EPS measure, which is mainly based on regulation of the fossil fuel energy sector, is a relatively good proxy for the overall environmental policy stringency of the country.

- Differences in policy enforcement. The EPS indicator is a de jure measure and does not capture differences across countries in the implementation and enforcement of policies. The World

19. Countries excluded are: Norway, France, Sweden and Canada. 
Economic Forum's survey-based indicator of environmental regulation enforcement can be used to test for the importance of the differences in policy enforcement. The WEF enforcement variable is used to divide countries into high and low enforcement countries, relative to the median value over the entire available sample. Countries with an average level of enforcement higher than the median of the sample are attributed a 1 for the dummy, while others a zero. This dummy is interacted with the EPS variable because the fixed effect estimation of the model will render all other country specific, time invariant variables redundant. At all the three layers of analysis, the interaction term is not significant, while the main explanatory variable is significant and stable in term of the coefficient estimate.

54. Additional robustness tests concern the robustness to the poor coverage of some firm sizes (in particular small firms) in the OECD-ORBIS database, different DTF specifications and some simple tests of reverse causality. The robustness of the results is generally confirmed. ${ }^{20}$

\subsection{Additional hypotheses tested}

55. Additional hypotheses are tested across the macro, industry and firm's specifications (see Appendix 2 for details). The results for tests of the importance of EPS levels and of the differential effects of market and non-market EPS instruments are discussed below, while additional tests for the double dividend hypothesis are reported in Appendix 2.

\section{Dependency on EPS levels}

56. The economic effect of the same change in environmental policy stringency may depend on whether a country has lax or tight environmental policies. On the one hand, further tightening in an already highly regulated country can be expected to be more detrimental than in a set-up where almost no regulation exists. On the other hand, the marginal effect of the tightening may be smaller if environmental policies are already stringent. To verify these conjectures a different specification is estimated: the change in the EPS variable is interacted with a dummy indicating whether the country is above or below the sample median level of environmental policy stringency.

57. No evidence is found that the country's level of environmental policy stringency affects the results: the temporary effect in productivity growth resulting from policy tightening is similar across countries, regardless of whether they have a high or low level of environmental regulation.

\section{Market-based instrument versus non-market instruments}

58. Market-based environmental policy instruments, which are based on explicit price signals, are generally considered to be more cost effective than non-market ones (De Serres et al., 2010). For instance, under an emission trading scheme firms have more flexibility in choosing the technology and timing of adjustment, than in a scheme of rigid technology standards. Hence, firms subject to market-based instruments can be expected to experience less detrimental effects on productivity growth. To investigate whether the effect of EPS changes on MFP growth varies with the design features of the environmental

20. These include three types of tests. 1) whether the results are robust to reweighting the ORBIS sample (by firm size) using data from national business registries, 2) different types of fixed effects, which can cause differences in the interpretation of the coefficients, 3) Simple regressions of changes in EPS on past MFP growth rates, controlling for fixed effects, with a general aim to account for factors such as political economy potentially driving the changes in EPS in response to past industry performance. 
policy instruments the country-level EPS index is split into market-based and non-market policies (see Figure 1). ${ }^{21}$

59. Empirical results across the three level of analysis yield some support for the cost-efficiency argument of the policy mix. At the macro level, the effect of market-based instruments on macro productivity growth is more robust than that of non-market instruments (Table A2.2). The coefficients of the non-market component of the EPS are not significant, while the effects of the market-based component remain significant. Similar results are found at the firm level the market-based instruments show a positive significant coefficient whereas the non-market instruments have no significant effect on productivity growth (Table A2.4). The effect of the interaction with the distance to frontier is negative and strongly significant for the non-market component, while less robust and significant for the market-based one. The marginal effect of the two groups of instruments differs considerably (Figure 13).

Figure 13. Marginal effect: market-based versus non-market EPS tightening
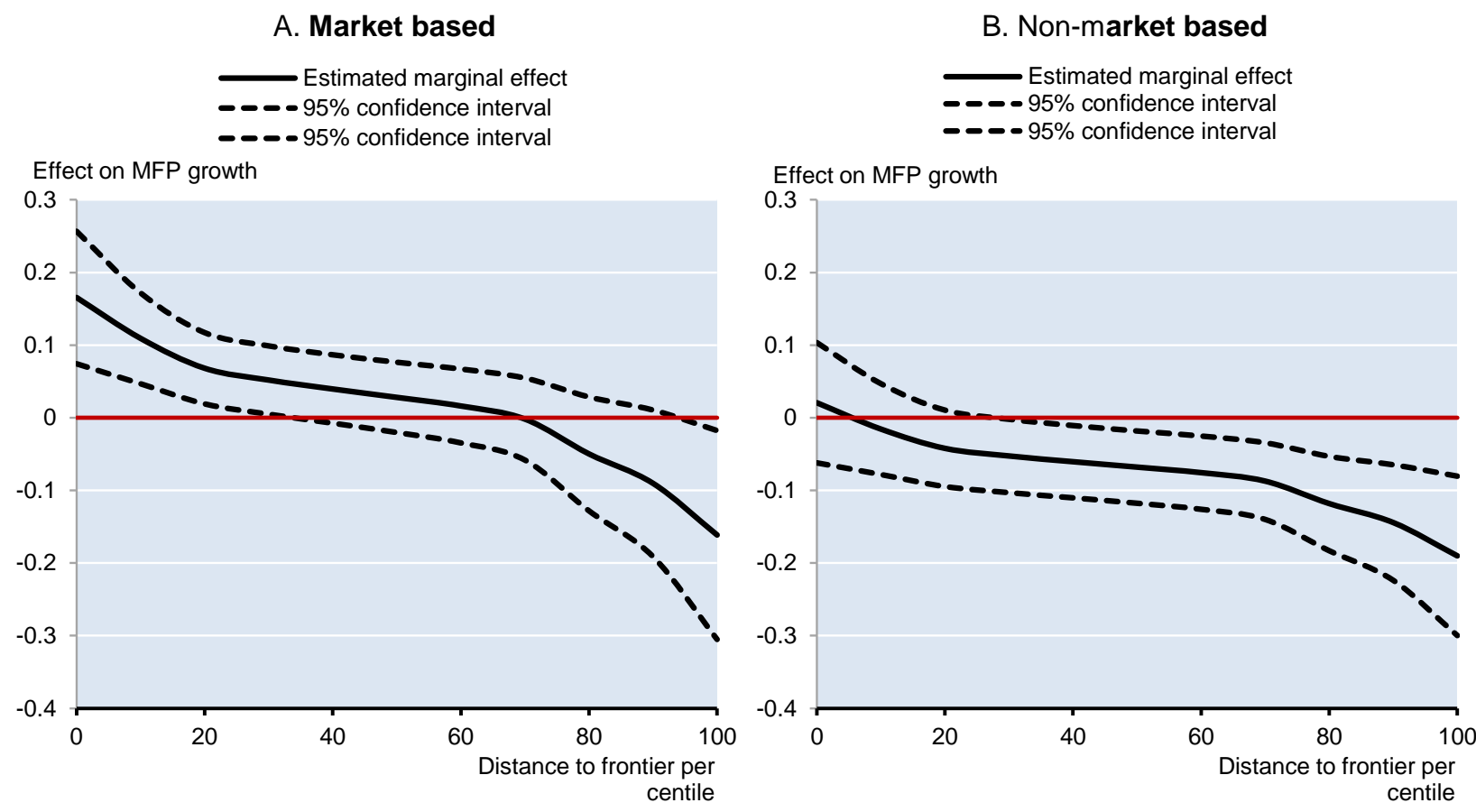

Note: $95 \%$ confidence intervals are reported (dotted lines).

60. At the industry level (Table A2.3) the effect of non-market policies is still significant even if not stable. The magnitude of the estimates is similar across the two sub-components. The interaction term with the distance to frontier is not robust anymore, suggesting that market-based instrument do not penalise

21. Results based on sub-indexes need to be interpreted cautiously as the main strength of the EPS index lies in the wealth of information across different policies - which together proxy for overall stringency of a much broader policy basket. 
low-productive industries. ${ }^{22}$ Furthermore, as regards the difference between the firm-level and industrylevel results, it is again likely to be driven by firm entry/exit dynamics.

\section{Discussion of results and conclusions}

61. The effect of a change in environmental policy stringency on productivity growth has been tested at three different aggregation levels (country, industry and firm) in a panel of OECD countries over the last 20 years. The bottom-line result is that, overall, an increase in stringency of environmental policies does not harm productivity growth or productivity levels - neither at the level of the entire economy nor at that of manufacturing industries. In fact, a tightening in environmental policy stringency is associated with a subsequent short-run increase in productivity growth, for the economy as a whole and in particular for the most productive industries and firms. However, less productive firms experience a fall in MFP growth, suggesting that the increase in productivity found at more aggregate levels partly reflect the exit of least productive firms from the market. Interestingly, the temporary effect in productivity growth resulting from policy tightening is similar across countries, regardless of whether they have a high or low level of environmental regulation.

62. Industry-based evidence shows a gain in productivity growth from a tightening in environmental stringency for most technologically advanced countries. This finding is confirmed only partially at the firm level, where only one-tenth of firms are able to reap productivity gains after a change in environmental regulation, while the least productive firms, one-third of the sample, face a negative effect. Highly productive firms, which are often the largest firms in the industry, may be best suited to profit rapidly from changing conditions - through seizing new market opportunities, rapid deployment of new technologies or reaping previously overseen efficiency gains (as implied by the Porter's Hypothesis), but potentially also through outsourcing and relocating parts of production abroad. The most productive firms can, on the one hand, draw on the most advanced technologies already, and, on the other hand, are likely to have more resources to invest into $R \& D$ or knowledge-based capital, for instance anticipating the environmental policy tightening. Less advanced firms, which are also likely to be smaller firms, may need higher investments to comply with the new regulation, for instance by adopting cleaner technologies or exchanging equipment, hence exhibiting a temporary fall in productivity growth.

63. Market-based environmental policy instruments are found to be more friendly to productivity growth than non-market instruments. Explicit price signals provide firms with higher flexibility in the abatement process, by allowing them to choose either the most suitable technology solution or the timing of the adjustment. These findings can be seen as tentative support to the idea that market-based instruments are more cost effective than command and control policies.

64. Further research on the effects of environmental policy stringency on investment patterns, entryexit, international trade and relocation, would help to shed more light on the channels through which productivity effects materialise, as well as, to understand broader economic effects of environmental policies. A closer look at investment, employment and production processes is needed to understand the full consequences of environmental policies. Finally, refinements and improvements to the measure of environmental policy stringency, such as the inclusion of additional policy instruments, sectors and countries would contribute to the robustness and comprehensiveness of such analysis, and allow expanding it to developing countries and emerging economies.

22. This result is not due to a selection bias - countries at the frontier experience a similar composition of tightening of EPS (in terms of market and non-market instruments) as countries further from the frontier (Figure A2.1). 


\section{REFERENCES}

Acemoglu, D., P. Aghion and F. Zilibotti (2006), "Distance to Frontier, Selection and Economic Growth", Journal of the European Economic Association, Vol. 4(1), pp. 37-74.

Ackerberg, D. A., K. Caves and G. Frazer (2006), "Structural Identification of Production Functions", mimeo.

Aghion, P. and P. Howitt (2006), "Joseph Schumpeter Lecture: Appropriate Policy Growth: A Unifying Framework", Journal of the European Economic Association, Vol. 4(2-3), pp. 269-314.

Alemani, E., C. Klein, I. Koske, C. Vitale and I. Wanner (2013), "New Indicators of Competition Law and Policy in 2013 for OECD and Non-OECD Countries", OECD Economics Department Working Paper, No. 1104, OECD Publishing.

Alpay, E., S. Buccola and J. Kerkvliet (2002), "Productivity Growth and Environmental Regulation in Mexican and U.S. Food Manufacutring", American Journal of Agricultural Economics, Vol. 84(4), pp. 887-901.

Ambec, S., M. A. Cohen, S. Elgie and P. Lanoie (2013), "The Porter Hypothesis at 20: Can Environmental Regulation Enhance Innovation and Competitiveness?", Review of Environmental Economics and Policy, Vol. 7(1), pp. 2-22.

Arnold, J., G. Nicoletti and S. Scarpetta (2008), "Regulation, Allocative Efficiency and Productivity in OECD Coutnries: Industry and Firm-Level Evidence", OECD Economics Department Working Papers, No. 616, OECD Publishing.

Barbera, A. J. and V. D. McConnell (1990), "The Impact of Environmental Regulations on Industry Productivity: Direct and Indirect Effects", Journal of Environmental Economics and Management, Vol. 18(1), pp. 50-65.

Bas M., A. Johansson, F., Murtin and G. Nicoletti (2013), "Do lower tariffs on foreign intermediate inputs raise productivity? Panel data evidence for OECD countries", OECD Economics Department Working Papers, forthcoming, OECD Publishing.

Becker, R. A. (2011), "Local environmental regulation and plant-level productivity", Ecological Economics, Vol. 70(12), pp. 2513-2522.

Berman, E. and L. T. M. Bui (2001), "Environmental Regulation and Productivity: Evidence from Oil Refineries", The Review of Economics and Statistics, Vol. 83(3), pp. 498-510.

Botta, E. and T. Koźluk (2014), "Measuring Environmental Policy Stringency in OECD Countries - A Composite Index Approach", OECD Economics Department Working Paper, No. 1177, OECD Publishing.

Bouis, R., R. Duval and F. Murtin (2011), "The Policy and Institutional Drivers of Economic Growth Across OECD and Non-OECD Economies: New Evidence from Growth Regressions", OECD Economics Department Working Papers, No. 843, OECD Publishing. 
Bourlès, R., G. Cette, J. Lopez, J. Mairesse and G. Nicoletti (2013), "Do product market regulations in upstream sectors curb productivity growth? Panel data evidence for OECD Countries", Review of Economics and Statistics 95, 1750-1768

Conway, P., de Rosa, D., Nicoletti, G. and Steiner, F. (2006), "Product market regulation and productivity convergence", OECD Economic Studies, vol. 2006(2), pages 39-76, OECD Publishing.

Dasgupta, S., Mody, A., Roy, S., Wheeler D. (1995), "Environmental regulation and development: a crosscountry empirical analysis", Policy Research Working Paper, No 1448. Policy Research Department, World Bank, Washington.

De Serres, A., F. Murtin and G. Nicoletti (2010), "A Framework for Assessing Green Growth Policies", OECD Economics Department Working Papers, No. 774, OECD Publishing.

Dufour, C., P. Lanoie and M. Patry (1998), "Regulation and productivity", Journal of Productivity Analysis, Vol. 9(3), pp. 233-247.

EBRD (2011), "Political Economy of Climate Change Policy in the Transition Region", The Low Carbon Transition, Chapter 4, EBRD publishing.

Gal, P. N. (2013), "Measuring Total Factor Productivity at the firm Level using OECD-ORBIS", OECD Economics Department Working Papers, No. 1049, OECD Publishing.

Gollop, F. M. and M. J. Roberts (1983), "Environmental Regulations and Productivity Growth: The Case of Fossil-fueled Electric Power Generation", Journal of Political Economy, Vol. 91(4), pp. 654-674.

Gonnard, E. and Ragoussis, A. (2013), "The OECD-ORBIS database treatment and benchmarking procedures", forthcoming, OECD working paper, OECD Publishing.

Gordon, RJ. (2012) "Is U.S. Economic Growth Over? Faltering Innovation and the Six Head-Winds", NBER Working Paper, No. 18315.

Gray, W. B. (1987), "The Cost of Regulation: OSHA, EPA and the Productivity Slowdown", The American Economic Review, Vol. 77(5), pp. 998-1006.

Gray, W. B. and R. J. Shadbegian (2003), "Plant vintage, technology, and environmental regulation", Journal of Environmental Economics and Management, Vol. 46(3), pp. 384-402.

Greenstone, M., J. List and C. Syverson (2012), "The effects of environmental regulation on the competitiveness of U.S. manufacturing”, NBER Working Paper Series, No. 18392, National Bureau of Economic Research, Cambridge Massachusetts.

Hamamoto, M. (2006), "Environmental regulation and the productivity of Japanese manufacturing industries", Resource and Energy Economics, Vol. 28(4), pp. 299-312.

Hoj, J. (2007), "Competition Law and Policy Indicators for the OECD Countries", OECD Economics Department Working Paper No. 568, OECD Publishing, Paris.

Jeon, B. M. and R. C. Sickles (2004), "The Role of Environmental Factors in Growth Accounting", Journal of Applied Econometrics, Vol. 19(5), pp. 567-591. 
Johansson. Å., Y. Guillemette, F. Murtin, D. Turner, G. Nicoletti, C. de la Maisonneuve, P. Bagnoli, G. Bousquet and F. Spinelli (2013), "Long-Term Growth Scenarios", OECD Economics Department Working Papers, No. 1000, OECD Publishing.

Johnstone, N., I. Haščič and M. Kalamova (2010), "Environmental Policy Design Characteristics and Technological Innovation: Evidence from Patent Data", OECD Environment Working Papers, No. 16, OECD Publishing.

Koźluk, T. and V. Zipperer (2014), "Environmental Policies and Productivity Growth: A Critical Review of Empirical Findings", OECD Journal: Economic Studies.

Lanoie, P., M. Patry and R. Lajeunesse (2008), "Environmental regulation and productivity: testing the Porter hypothesis", Journal of Productivity Analysis, Vol. 30(2), pp. 121-128.

Levinsohn, J. and A. Petrin (2003), "Estimating Production Functions Using Inputs to control for Unobservables", Review of Economic Studies, Vol. 70(2), pp. 317-341.

Nicoletti, G. and S. Scarpetta (2003), "Regulation, Productivity, and Growth: OECD Evidence", Policy Research Working Paper, No. 2944.

Nicoletti, G., S. Scarpetta and O. Boylaud (2000), "Summary Indicators of Product Market Regulation with an Extension to Employment Protection Legislation", OECD Economics Department Working Papers, No. 226, OECD Publishing.

Porter, M. (1991), “America’s green strategy”, Scientific American, Vol. 264(4), p.168.

Porter, M. E. and C. van der Linde (1995), "Toward a New Conception of the Environment Competitiveness Relationship", Journal of Economic Perspectives, Vol. 9(4), pp. 97-118.

Rajan, R. G. and L. Zingales (1998), "Financial Dependence and Growth", The American Economic Review, Vol. 88(3), pp. 559-586.

Smith, J. B. and W. A. Sims (1985), "The impact of pollution charges on productivity growth in Canadian brewing", The RAND Journal of Economics, Vol. 16(3), pp. 410-423.

Westmore, B. (2013), "R\&D, Patenting and Growth", OECD Economics Department Working Papers, No. 1047, OECD Publishing.

Woodridge, J. M. (2009), "On estimating firm-level production functions using proxy variables to control for unobservables”, Economic Letters, Vol. 104(3), pp. 112-114.

Wu, Y. and B. Wang (2008), "Environmental Regulation and Total Factor Productivity Growth: An Empirical Study of the APEC Economies", Economic Research Journal, Vol. 43(5), pp. 19-33.

Yang, C.-H., Y.-H. Tseng and C.-P. Chen (2012), "Environmental regulations, induced R\&D, and productivity: Evidence from Taiwan's manufacturing industries", Resource and Energy Economics, Vol. 34(4), pp. 514-532.

Yörük, B. K. and O. Zaim (2005), "Productivity growth in OECD countries: A comparison with Malmquist indices", Journal of Comparative Economics, Vol. 33(2), pp. 401-420. 


\section{APPENDIX 1 - DATA DESCRIPTION}

\section{Table A1.1 Description of the variables}

\begin{tabular}{|c|c|c|c|c|c|c|}
\hline \multirow[t]{2}{*}{ Variables } & \multicolumn{3}{|c|}{ Included in the econometric specification: } & \multirow[t]{2}{*}{ Description } & \multirow[t]{2}{*}{ Dimensions } & \multirow[t]{2}{*}{ Source } \\
\hline & Country & Industry & Firm & & & \\
\hline \multirow{3}{*}{$\begin{array}{l}\text { Multi-factor } \\
\text { productivity index }\end{array}$} & $\mathrm{x}$ & \multirow{3}{*}{$\mathrm{x}$} & & $\begin{array}{l}\text { The MFP is derived from a standard production function } \\
\text { which includes physical capital, human capital and labour } \\
\text { as production factors. }\end{array}$ & country, time & Johansson et al (2013) \\
\hline & & & & $\begin{array}{l}\text { Industry level MFP estimates are constructed as residuals } \\
\text { considering a standard capital-labour Cobb-Douglas } \\
\text { production function. Growth rates are calculated as a two- } \\
\text { year moving average. }\end{array}$ & $\begin{array}{l}\text { country-industry, } \\
\text { time }\end{array}$ & $\begin{array}{l}\text { OECD STAN database and } \\
\text { OECD Industry Productivity } \\
\text { database }\end{array}$ \\
\hline & & & $\mathrm{x}$ & $\begin{array}{l}\text { At the firm level the index of multifactor productivity is } \\
\text { constructed following the approach in Woodridge (2009). }\end{array}$ & country-firm, time & ORBIS database \\
\hline \multirow{3}{*}{$\begin{array}{l}\text { Technological } \\
\text { leader (frontier) }\end{array}$} & $x$ & \multirow{3}{*}{$\mathrm{x}$} & & Highest MFP by country and year & country, time & Johansson et al (2013) \\
\hline & & & & $\begin{array}{l}\text { Highest MFP by industry and year - corrected for outliers, } \\
\text { following Bas et al. (2013). }\end{array}$ & industry, time & $\begin{array}{l}\text { OECD STAN database and } \\
\text { OECD Industry Productivity } \\
\text { database }\end{array}$ \\
\hline & & & $\mathrm{x}$ & $\begin{array}{l}\text { MFP average of the top } 5 \% \text { performers across countries, } \\
\text { by industry and year, corrected for outliers. }\end{array}$ & industry, time & ORBIS database \\
\hline \multirow{3}{*}{$\begin{array}{l}\text { Distance to } \\
\text { frontier }\end{array}$} & $x$ & \multirow{3}{*}{$\mathrm{x}$} & & In (MFP "Technological leader") - In(MFP country), first lag & country, time & Johansson et al (2013) \\
\hline & & & & $\begin{array}{l}\text { In (MFP "Technological leader") - In(MFP country-industry } \\
\text { pair), first lag }\end{array}$ & industry, time & $\begin{array}{l}\text { OECD STAN database and } \\
\text { OECD Industry Productivity } \\
\text { database }\end{array}$ \\
\hline & & & $x$ & In (MFP "Technological leader") - In (MFP firm), first lag & firm, time & ORBIS database \\
\hline
\end{tabular}


ECO/WKP(2014)75

Environmental

Changes in EPS index interacted with environmental dependence (22 subsector decomposition), three-year moving average.

Demand trend

Total assets defined as turnover (in logs), first lag

Chinn-lto index measuring a country's degree of capital account openness - based on the binary dummy variables that codify the tabulation of restrictions on cross-border financial transactions reported in the IMF's Annual Report on Exchange Arrangements and Exchange Restrictions (AREAER), first lag.

\section{openness}

policy stringency

country-industry,

time

OECD (2014), WB

country-industry

time

OECD (2014), WB

firm, time

ORBIS

country, time

Chinn and Ito, Journal of Development Economics, 2006

Cyclical component of real GDP, HP filter

country, time

OECD National accounts

$\begin{array}{ll}\text { Economic cycle } & X \\ \text { Employment } & X\end{array}$

Protection

Strictness of employment protection - individual and collective dismissals, first lag.

country, time

OECD

Strictness of employment protection - individual and collective dismissals, interacted with firm's pre-sample

number of employees, first lag.

country-firm, time OECD

\begin{tabular}{|c|c|c|c|c|c|c|}
\hline \multirow{2}{*}{ Financial crisis } & $\mathrm{x}$ & & $x$ & Dummy for year 2008 and dummy for year 2009 & time & \\
\hline & & $\mathrm{x}$ & & Dummy for year 2007 to 2009 & time & \\
\hline \multirow{2}{*}{$\begin{array}{l}\text { Financial } \\
\text { development }\end{array}$} & $\mathrm{x}$ & & & $\begin{array}{l}\text { Ratio of bank credit plus stock market capitalisation to } \\
\text { GDP (both in USD PPP), first lag. }\end{array}$ & country, time & $\begin{array}{l}\text { WB Development } \\
\text { Indicators }\end{array}$ \\
\hline & & & $\mathrm{x}$ & $\begin{array}{l}\text { Same as for country analysis, weighted by the financial } \\
\text { exposure of the industry (measures as input of financial } \\
\text { insurance sector to the manufacturing sector). }\end{array}$ & industry, time & $\begin{array}{l}\text { WB Development } \\
\text { Indicators, OECD STAN }\end{array}$ \\
\hline Hours worked & $\mathrm{x}$ & & & Hours worked per employee, total economy, growth rate & country, time & $\begin{array}{l}\text { OECD Economic Outlook } 85 \\
\text { database }\end{array}$ \\
\hline
\end{tabular}


Industry share in GDP: Sum of value added of ISIC divisions

10-45 (mining, manufacturing, construction, electricity,

water, and gas) divided by gross value added at factor cost.

Primary balance $\quad \mathrm{X} \quad$ General government underlying primary balances, surplus or deficit as percent of potential GDP.

OECD Green Growth

country, time Indicators

Dummy variable which takes the value 1 for PMR levels above the median and 0 below. Uses the three vintages of the PMR: distribution of the 1998 PMR is used to construct dummy for 1990 - 2000. Indicator values of 2003 and 2008 are attributed to the time periods $2001-2005$ and 2006 2010, respectively.

\section{Product Market}

Regulation (PMR)

\section{Regulatory Impact}

(RI)

R\&D expenditure

\begin{tabular}{lll} 
Firms' size & $\mathrm{X}$ & $\mathrm{X}$ \\
\hline Time trend & $\mathrm{X}$ & $\mathrm{X}$ \\
& $\mathrm{X}$ & \\
Trade Openness & $\mathrm{X}$ & $\mathrm{X}$ \\
& & \\
&
\end{tabular}

The indicators on regulatory impact (RI) quantify the potential costs of the anti-competitive regulation captured by the indicators on sector regulation on 39 sectors of the economy that use the output of these sectors as intermediate inputs.

Business enterprise R\&D expenditure (BERD) as share over GDP (real terms), moving average which includes lag one, two and three

Expenditure in R\&D over value added (real terms), first lag Number of employees (log), first lag Year trend

Trade-to-GDP, calculated as the sum of exports and imports divided by GDP, constant prices, constant exchange rates, OECD base year 2000 , first lag.

Trade openness is defined as the sum of import and export over the production (real terms). If production is not available the value added is used as denominator, first lag.

North sea crude oil annual spot price in US\$, deflated with uS\$ deflator; first difference, first lag.

OECD Economic Outlook 85 database

country, time

OECD Product Market

Regulation Database (2014

update)

industry, time

OECD Regulatory Impact

country, time

OECD Business enterprise $R \& D$ expenditure Database

country-industry

OECD STAN

time

ORBIS

firm, time

time

country, time OECD Macro Trade

Indicators

industry, time $\quad$ OECD STAN

country, time

OECD Crude Oil Spot Prices

Database 


\section{APPENDIX 2 - ADDITIONAL HYPOTHESIS TESTED}

1. The exact timing of the effect of a change in environmental policy stringency on productivity growth is likely to depend on the policy and its implementation and announcement details. As such the effect may only show up in later years and can differ in terms of timing. Table A2.1 shows results for the macro baseline specification, as well as for the specification with additional controls for up to six lags of a change in EPS. In each specification, one lag after the other is added. The first lag is not significant whereas lag two and three seem to have a significant positive effect on productivity growth, robust to the inclusion of additional controls. Further lags are included, but do not bring any robust, significant results. Considering the relatively short sample of only 19 years, the significance of the individual lags and for the reasons mentioned above concerning the timely difference of impacts of environmental policies, a threeyears moving average is adopted in the analysis. This moving average includes the lags one, two and three. This approach has been applied consistently across all three levels of analysis, due to similar results and argument. 


\section{Table A2.1 Macro level: Testing different lag structures}

\begin{tabular}{|c|c|c|c|c|c|c|c|c|c|c|c|c|}
\hline $\begin{array}{c}\text { Dependent variable: } \\
\text { MIFP growth }\end{array}$ & 1 & 2 & 3 & 4 & 5 & 6 & 7 & 8 & 9 & 10 & 11 & 12 \\
\hline & Baseline & $\begin{array}{c}\text { Baseline + } \\
\text { controls }\end{array}$ & Baseline & $\begin{array}{c}\text { Baseline + } \\
\text { controls }\end{array}$ & Baseline & $\begin{array}{c}\text { Baseline + } \\
\text { controls }\end{array}$ & Baseline & $\begin{array}{c}\text { Baseline + } \\
\text { controls }\end{array}$ & Baseline & $\begin{array}{c}\text { Baseline + } \\
\text { controls }\end{array}$ & Baseline & $\begin{array}{c}\text { Baseline + } \\
\text { controls }\end{array}$ \\
\hline \multirow[t]{2}{*}{$\begin{array}{l}\text { Growth of MFP of } \\
\text { technology leader }\end{array}$} & $0.377 * * *$ & $0.388 * * *$ & $0.359 * * *$ & $0.386^{* * *}$ & $0.356^{* * *}$ & $0.363 * * *$ & $0.330 * * *$ & $0.322 * * *$ & $0.348 * * *$ & $0.366^{* * *}$ & $0.441 * * *$ & $0.490 * * *$ \\
\hline & $(0.0628)$ & $(0.0653)$ & $(0.0695)$ & $(0.0702)$ & $(0.0660)$ & $(0.0671)$ & $(0.0631)$ & $(0.0673)$ & $(0.0645)$ & $(0.0660)$ & $(0.0683)$ & $(0.0824)$ \\
\hline \multirow[t]{2}{*}{$\begin{array}{c}\text { Technology gap in MFP } \\
\text { levels (t-1) }\end{array}$} & $0.104 * * *$ & $0.0974 * * *$ & $0.111 * * *$ & $0.0977 * * *$ & $0.114 * * *$ & $0.0978 * * *$ & $0.126 * * *$ & $0.108^{* * *}$ & $0.148 * * *$ & $0.116^{* * *}$ & $0.0912 * * *$ & $0.113^{* * *}$ \\
\hline & $(0.0193)$ & $(0.0207)$ & $(0.0211)$ & $(0.0206)$ & $(0.0224)$ & $(0.0205)$ & $(0.0243)$ & $(0.0202)$ & $(0.0287)$ & $(0.0228)$ & $(0.0195)$ & $(0.0242)$ \\
\hline \multirow[t]{2}{*}{ Change in EPS in $\mathrm{t}-1$} & -0.00256 & -0.000485 & -0.00160 & -0.000119 & -0.00132 & 0.000721 & -0.00224 & -0.000960 & -0.00287 & -0.000723 & 0.00362 & -0.00124 \\
\hline & $(0.00490)$ & $(0.00533)$ & $(0.00524)$ & $(0.00504)$ & $(0.00551)$ & $(0.00556)$ & $(0.00513)$ & $(0.00511)$ & $(0.00506)$ & $(0.00485)$ & $(0.00403)$ & $(0.00488)$ \\
\hline \multirow[t]{2}{*}{ Change in EPS in $\mathrm{t}-2$} & & & $0.00635^{*}$ & $0.00848 * *$ & $0.00729 *$ & $0.00967 * *$ & 0.00544 & $0.00843 * *$ & 0.00337 & $0.00752 *$ & 0.00181 & $0.00743^{*}$ \\
\hline & & & $(0.00363)$ & $(0.00339)$ & $(0.00408)$ & $(0.00374)$ & $(0.00437)$ & $(0.00380)$ & $(0.00223)$ & $(0.00365)$ & $(0.00265)$ & $(0.00386)$ \\
\hline \multirow[t]{2}{*}{ Change in EPS in $\mathrm{t}-3$} & & & & & 0.00550 & $0.00455^{*}$ & 0.00492 & 0.00448 & 0.00464 & $0.00382 * *$ & -0.000292 & 0.00246 \\
\hline & & & & & $(0.00322)$ & $(0.00239)$ & $(0.00412)$ & $(0.00307)$ & $(0.00442)$ & $(0.00144)$ & $(0.00244)$ & $(0.00185)$ \\
\hline \multirow[t]{2}{*}{ Change in EPS in $\mathrm{t}-4$} & & & & & & & 0.0000530 & 0.00437 & 0.000445 & -0.00124 & $-0.00390 *$ & -0.00193 \\
\hline & & & & & & & $(0.00388)$ & $(0.00310)$ & $(0.00458)$ & $(0.00163)$ & $(0.00192)$ & $(0.00183)$ \\
\hline \multirow[t]{2}{*}{ Change in EPS in $\mathrm{t}-5$} & & & & & & & & & 0.000112 & $0.00778^{* *}$ & -0.00191 & $0.00732 * *$ \\
\hline & & & & & & & & & $(0.00495)$ & $(0.00302)$ & $(0.00504)$ & $(0.00278)$ \\
\hline \multirow[t]{2}{*}{ Change in EPS in $\mathrm{t}-6$} & & & & & & & & & & & -0.00172 & 0.00203 \\
\hline & & & & & & & & & & & $(0.00552)$ & $(0.00566)$ \\
\hline Country fixed effects & Yes & Yes & Yes & Yes & Yes & Yes & Yes & Yes & Yes & Yes & Yes & Yes \\
\hline $\mathrm{N}$ & 354 & 298 & 333 & 293 & 314 & 277 & 294 & 260 & 274 & 243 & 254 & 226 \\
\hline Adj. R-squared & 0.616 & 0.678 & 0.638 & 0.688 & 0.653 & 0.706 & 0.660 & 0.724 & 0.675 & 0.741 & 0.690 & 0.757 \\
\hline
\end{tabular}

Note: Robust standard errors in parentheses; ${ }^{* * *}$ denotes statistical significance at the $1 \%$ level, ${ }^{* *}$ significance at $5 \%$ level, ${ }^{*}$ significance at $1 \%$ level.

Baseline specification includes the following controls: Output gap, growth rate of average hours worked per employee, time trend, dummies for crisis years 2007 and 2008 . Baseline + controls specification includes cyclically adjusted general government primary balance as percent of potential GDP, trade openness, industry share in $\%$ of total activity, business expenditure on R\&D as \% of GDP, employment protection legislation, product market regulation and the change in real oil price. 


\section{Market-based versus non-market instruments}

2. Tables A2.2, A2.3 and A2.4 report results that allow for differential effects of an EPS tightening using market and non-market instruments, as described in the paper. Figure A2.1, reports the distribution of EPS changes across the two categories of instruments.

\section{Table A2.2 Macro level: Market-based versus non-market instruments}

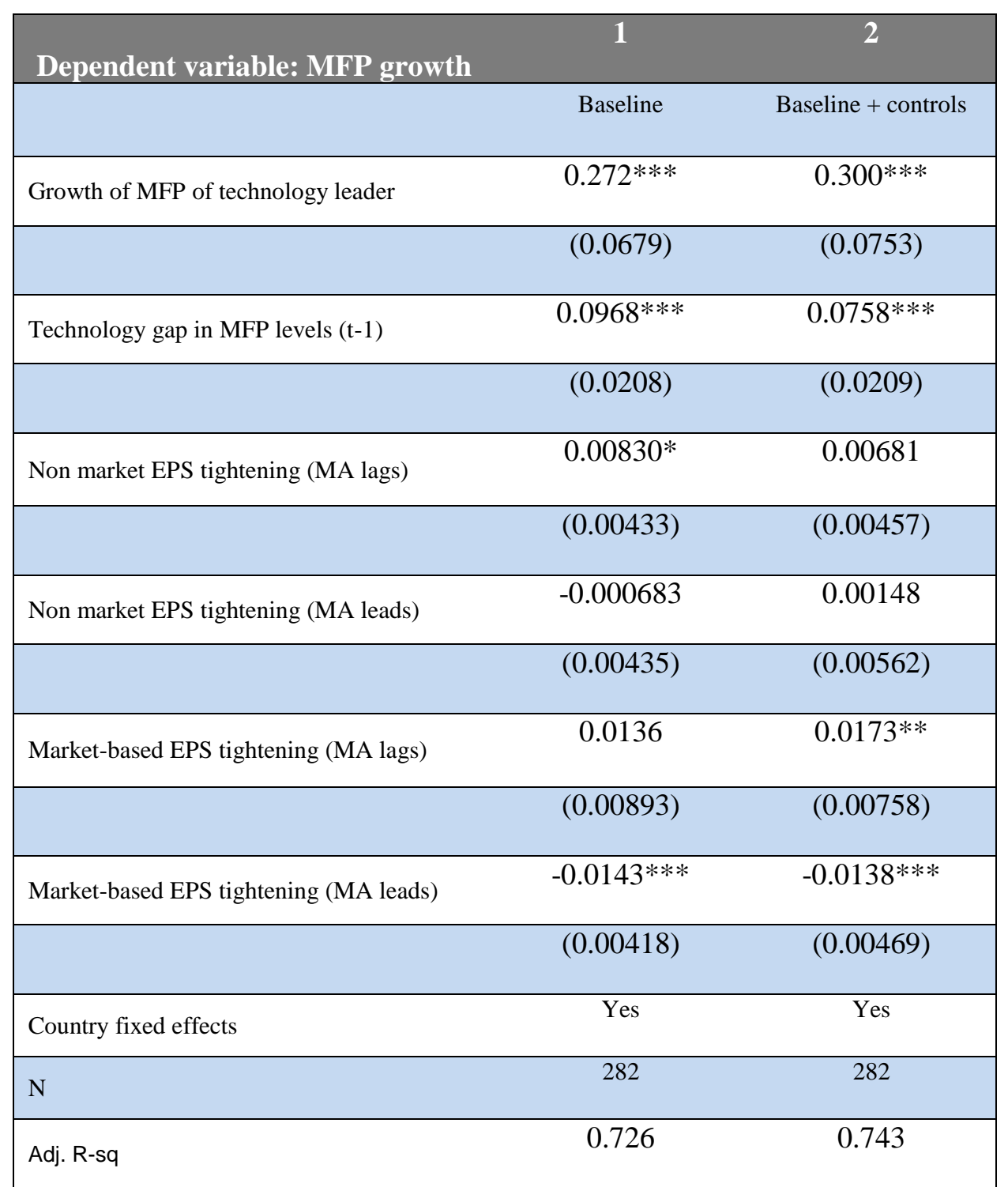

Note: Robust standard errors in parentheses; ${ }^{* * *}$ denotes statistical significance at the $1 \%$ level, ${ }^{* *}$ significance at $5 \%$ level, ${ }^{\text {* }}$ significance at $10 \%$ level.

(MA): denotes the moving average of the EPS change over three years (lagslleads).

Baseline specification includes the following controls: Output gap, growth rate of average hours worked per employee, time trend, dummies for crisis years 2007 and 2008. Baseline + controls specification includes cyclically adjusted general government primary balance as percent of potential GDP, trade openness, industry share in $\%$ of total activity, business expenditure on R\&D as \% of GDP, employment protection legislation, product market regulation and the change in real oil price. 
ECO/WKP(2014)75

Table A2.3 Industry level: Market-based versus non-market instruments

\begin{tabular}{|c|c|c|c|c|c|c|c|c|}
\hline Column1 & 1 & 2 & 3 & 4 & 5 & 6 & 7 & 8 \\
\hline & Baseline & Baseline & $\begin{array}{l}\text { Baseline + } \\
\text { Regulation }\end{array}$ & $\begin{array}{l}\text { Baseline + } \\
\text { Regulation }\end{array}$ & $\begin{array}{c}\text { Baseline + } \\
\text { Country/ind } \\
\text { controls }\end{array}$ & $\begin{array}{c}\text { Baseline + } \\
\text { Country/ind } \\
\text { controls }\end{array}$ & $\begin{array}{c}\text { Full set of } \\
\text { controls }\end{array}$ & $\begin{array}{c}\text { Full set of } \\
\text { controls }\end{array}$ \\
\hline \multirow[t]{2}{*}{ Leader MFP growth } & $0.152 * * *$ & $0.129 * * *$ & $0.150 * * *$ & $0.128 * * *$ & $0.129 * * *$ & $0.107 * * *$ & $0.126^{* * *}$ & $0.105^{* * *}$ \\
\hline & $(0.0277)$ & $(0.0283)$ & $(0.0274)$ & $(0.0282)$ & $(0.0288)$ & $(0.0292)$ & $(0.0286)$ & $(0.0293)$ \\
\hline \multirow[t]{2}{*}{$\begin{array}{l}\text { Distance to frontier } \\
\text { (lagged) }\end{array}$} & $0.172 * * *$ & $0.0919 * * *$ & $0.168 * * *$ & $0.0897 * * *$ & $0.170 * * *$ & $0.0917 * * *$ & $0.166^{* * *}$ & $0.0893 * * *$ \\
\hline & $(0.0264)$ & $(0.0131)$ & $(0.0251)$ & $(0.0127)$ & $(0.0258)$ & $(0.0126)$ & $(0.0244)$ & $(0.0121)$ \\
\hline \multirow[t]{2}{*}{$\begin{array}{l}\text { Market-based EPS } \\
\text { tightening (MA) }\end{array}$} & $0.0810^{* *}$ & $0.0787 * * *$ & $0.0846 * * *$ & $0.0826 * * *$ & $0.0985 * * *$ & $0.101 * * *$ & $0.100 * * *$ & $0.103 * * *$ \\
\hline & $(0.0247)$ & $(0.0204)$ & $(0.024)$ & $(0.0197)$ & $(0.0242)$ & $(0.0204)$ & $(0.0235)$ & $(0.0198)$ \\
\hline \multirow[t]{2}{*}{$\begin{array}{l}\text { Effect of gap on } \\
\text { market-based } \\
\text { tightening (MA) }\end{array}$} & -0.0644 & -0.0561 & -0.067 & -0.0578 & -0.0901 & $-0.092 *$ & -0.0917 & $-0.0926^{*}$ \\
\hline & $(0.0632)$ & $(0.0523)$ & $(0.0618)$ & $(0.051)$ & $(0.0605)$ & $(0.0494)$ & $(0.0586)$ & $(0.0479)$ \\
\hline \multirow[t]{2}{*}{$\begin{array}{l}\text { Non market EPS } \\
\text { tightening (MA) }\end{array}$} & $0.0679 * *$ & $0.0536 * *$ & $0.0694 * *$ & $0.0552 * *$ & $0.0584 * *$ & $0.0446^{* *}$ & $0.0585^{* *}$ & $0.0459 * *$ \\
\hline & $(0.0285)$ & $(0.0241)$ & $(0.0284)$ & $(0.0239)$ & $(0.0238)$ & $(0.0209)$ & $(0.0239)$ & $(0.0209)$ \\
\hline \multirow[t]{2}{*}{$\begin{array}{l}\text { Effect of gap on non } \\
\text { market EPS } \\
\text { tightening (MA) }\end{array}$} & $-0.146^{*}$ & $-0.108 *$ & $-0.149 * *$ & $-0.112 *$ & $-0.115 * *$ & -0.0771 & $-0.117 * *$ & $-0.0819^{*}$ \\
\hline & $(0.0744)$ & $(0.0637)$ & $(0.0742)$ & $(0.0633)$ & $(0.0562)$ & $(0.0485$ & $(0.0564)$ & $(0.0486)$ \\
\hline \multicolumn{9}{|l|}{ Fixed effects } \\
\hline Country*Industry & Yes & No & Yes & No & Yes & No & Yes & No \\
\hline Country & No & Yes & No & Yes & No & Yes & No & Yes \\
\hline Industry & No & Yes & No & Yes & No & Yes & No & Yes \\
\hline $\mathrm{N}$ & 2084 & 2084 & 2084 & 2084 & 1944 & 1944 & 1944 & 1944 \\
\hline adj. R2 & 0.122 & 0.171 & 0.126 & 0.176 & 0.126 & 0.19 & 0.129 & 0.194 \\
\hline
\end{tabular}

Note: Robust standard errors in parentheses and they are clustered at country-industry level; ${ }^{* * *}$ denotes statistical significance at the $1 \%$ level, ${ }^{*}$ significance at $5 \%$ level, ${ }^{*}$ significance at $10 \%$ level.

(MA): denotes the moving average of the EPS change over three years (lag).

Baseline specification includes the following controls: real GDP cycle, dummy for crisis and year trend. Baseline + Regulation includes: employment protection legislation (OECD EPL), product market regulation (OECD PMR) and country's degree of capital account openness (Chinn-Ito Index). Baseline + Country/ind. includes industry-specific time-varying controls, such as trade openness, R\&D expenditures, and real oil price. 
Figure A.2.1 Distribution of industry-EPS changes by instrument type and distance to the frontier
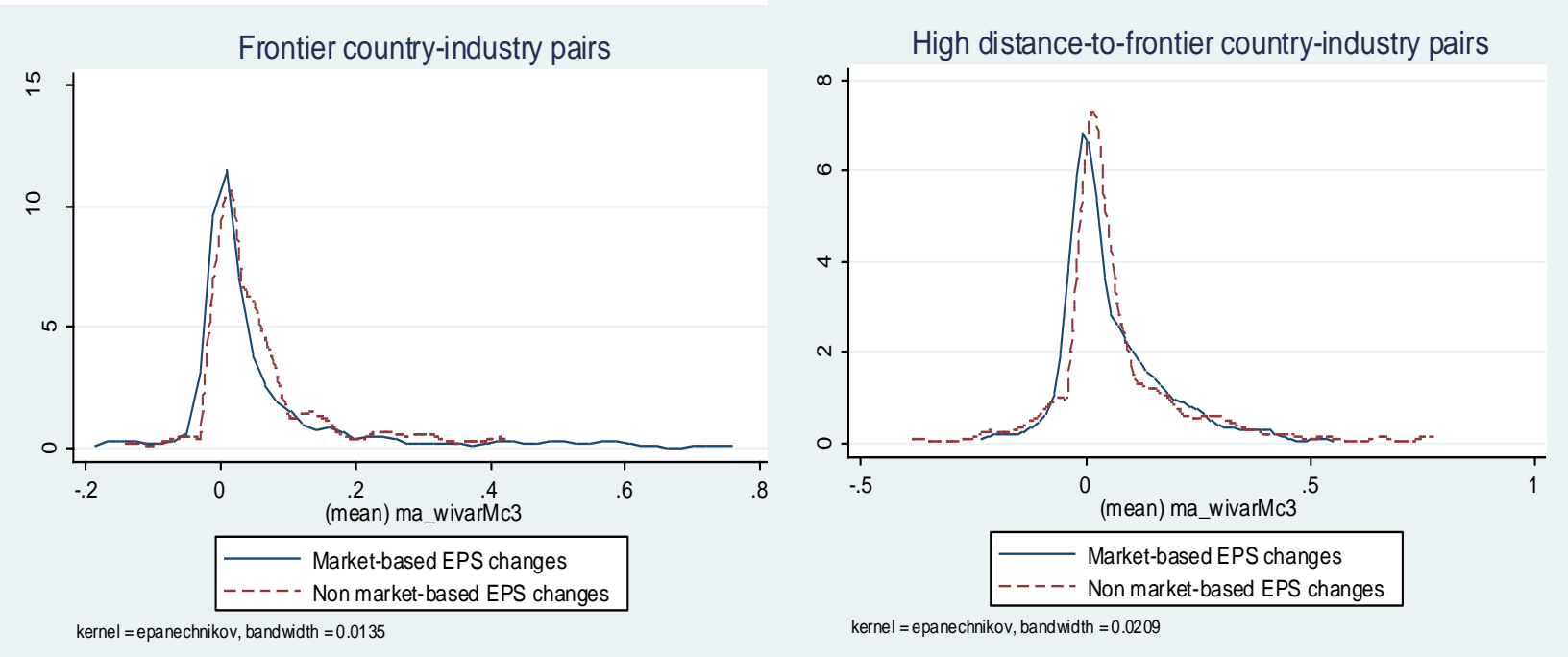
Table A2.4 Firm level: market-based and non-market instruments

\begin{tabular}{|c|c|c|c|c|c|c|}
\hline Dependent: MFP growth & 1 & 2 & 3 & 4 & 5 & 6 \\
\hline & Baseline & Baseline & $\begin{array}{c}\text { Baseline }+ \\
\text { Firm controls }\end{array}$ & $\begin{array}{c}\text { Baseline }+ \\
\text { Firm controls }\end{array}$ & Full sets of controls & Full sets of controls \\
\hline \multirow[t]{2}{*}{ Growth in MFP in the technology leader } & $0.0804 * * *$ & $0.106 * * *$ & $0.101 * * *$ & $0.148 * * *$ & $0.143 * * *$ & $0.185^{* * *}$ \\
\hline & $(0.0257)$ & $(0.0242)$ & $(0.0289)$ & $(0.0254)$ & $(0.0168)$ & $(0.0138)$ \\
\hline \multirow[t]{2}{*}{ Gap in MFP levels (t-1) } & $0.176 * * *$ & $0.224 * * *$ & $0.209 * * *$ & $0.294 * * *$ & $0.223 * * *$ & $0.297 * * *$ \\
\hline & $(0.0143)$ & $(0.00767)$ & $(0.0240)$ & $(0.0129)$ & $(0.0229)$ & $(0.0121)$ \\
\hline \multirow[t]{2}{*}{ Market-based EPS tightening (MA) } & $0.104 * *$ & $0.114 * *$ & $0.0959 * *$ & $0.101 *$ & $0.134 * * *$ & $0.166 * * *$ \\
\hline & $(0.0460)$ & $(0.0515)$ & $(0.0458)$ & $(0.0532)$ & $(0.0385)$ & $(0.0434)$ \\
\hline \multirow[t]{2}{*}{ Non-market EPS tightening (MA) } & $0.118 * * *$ & $0.133 * * *$ & $0.0915 * * *$ & $0.0884 * *$ & 0.0137 & -0.00114 \\
\hline & $(0.0351)$ & $(0.0394)$ & $(0.0347)$ & $(0.0390)$ & $(0.0361)$ & $(0.0361)$ \\
\hline \multirow[t]{2}{*}{ Effect of gap on market-based EPS tightening (MA) } & $-0.0321 * *$ & $-0.0352 * *$ & $-0.0294 * *$ & $-0.0297 *$ & $-0.0439 * * *$ & $-0.0553 * * *$ \\
\hline & $(0.0143)$ & $(0.0168)$ & $(0.0138)$ & $(0.0169)$ & $(0.0118)$ & $(0.0153)$ \\
\hline \multirow[t]{2}{*}{ Effect of gap on non-market EPS tightening (MA) } & $-0.0556 * * *$ & $-0.0684 * * *$ & $-0.0422 * * *$ & $-0.0503 * * *$ & -0.0243 & $-0.0274 *$ \\
\hline & $(0.0155)$ & $(0.0157)$ & $(0.0148)$ & $(0.0137)$ & $(0.0150)$ & $(0.0141)$ \\
\hline \multicolumn{7}{|l|}{ Fixed Effects } \\
\hline Country & Yes & No & Yes & No & Yes & No \\
\hline Industry & Yes & No & Yes & No & Yes & No \\
\hline Country*Industry & No & Yes & No & Yes & No & Yes \\
\hline Standard errors clustered at country*industry level & Yes & Yes & Yes & Yes & Yes & Yes \\
\hline Observations & 647392 & 647392 & 625011 & 625011 & 313071 & 313071 \\
\hline Adjusted R-squared & 0.091 & 0.114 & 0.102 & 0.138 & 0.099 & 0.131 \\
\hline
\end{tabular}

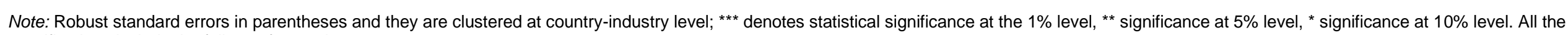
specifications include the full set of controls.

(MA): defined as the moving average of the EPS change over three years(lag).

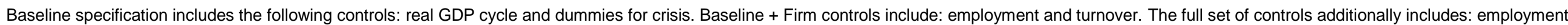
protection legislation (OECD EPL), regulatory impact indicator (OECD RI), financial development, trade openness and R\&D expenditures. 


\section{ECO/WKP(2014)75}

\section{Double-dividend hypothesis}

3. Some environmental policy instruments can potentially generate public revenues, which in turn can be used to reduce more distortive forms of taxations, to offset part of the EPS impact or to improve the government budget balance (see De Serres et al., 2010 for a comprehensive discussion). Such a 'double dividend' would be consistent with a higher productivity growth resulting from a revenue-generating EPS tightening. To test this, the EPS subcomponents are classified and aggregated according to the effect they might have on public finance: revenue increasing (taxes), revenue decreasing - in the strict sense (R\&D subsidies), and revenue neutral (standards, deposit and refund schemes, trading schemes, feed-in-tariffs). Such a classification, as well as the extent of the change in revenue, depends on the design features of the country-specific framework, and therefore it has to be taken with caution. In particular, in this case only macro and industry level analysis is conducted, as firm level analysis would necessarily imply looking for the "double dividend" benefits for the individual firms - a strong assumption which for verification would require very detailed information on policies. Furthermore, results based on sub-indexes need to be interpreted cautiously as the main strength of the EPS index lies in the wealth of information across different policies - which together proxy for overall stringency of a much broader policy basket.

4. At the macro level, no support is found for the double dividend hypothesis. Table A2.5 displays the results where the preferred specification (2) shows a significant effect on productivity growth for "revenue-increasing" and "revenue-neutral" instruments. The negative anticipation effect is however only found for 'revenue-neutral' instruments.

5. Table A2.6 reports the industry-level results considering the three subcomponents in the standard framework of this analysis. The estimates do not seem to support this hypothesis. Similarly, by looking at the coefficients of the interaction variable $\left(E D_{i 1987} \Delta E P S_{c t-j}\right)$ this specification would implicitly assume that the benefits of the dividend would be proportional to environmental dependence, which is not obvious. 
ECO/WKP(2014)75

Table A2.5 Macro level: the double-dividend hypothesis

\begin{tabular}{|c|c|c|}
\hline Dependent variable: MFP growth & 1 & 2 \\
\hline & Baseline & $\begin{array}{l}\text { Baseline } \\
+ \text { controls }\end{array}$ \\
\hline \multirow[t]{2}{*}{ Growth of TFP of technology leader } & $0.353 * * *$ & $0.346 * * *$ \\
\hline & $(0.0637)$ & $(0.0632)$ \\
\hline \multirow[t]{2}{*}{ Technology gap in TFP levels (t-1) } & $0.114 * * *$ & $0.102 * * *$ \\
\hline & $(0.0191)$ & $(0.0208)$ \\
\hline \multirow[t]{2}{*}{ Revenue increasing EPS tightening (MA) } & $0.00691 *$ & $0.00976^{* *}$ \\
\hline & $(0.00369)$ & $(0.00423)$ \\
\hline \multirow[t]{2}{*}{$\begin{array}{l}\text { Average EPS change in } t+1 \text { - revenue } \\
\text { increasing instruments }\end{array}$} & -0.000309 & -0.000820 \\
\hline & $(0.00418)$ & $(0.00378)$ \\
\hline \multirow[t]{2}{*}{ Revenue neutral EPS tightening (MA) } & 0.00704 & $0.00765^{* *}$ \\
\hline & $(0.00428)$ & $(0.00312)$ \\
\hline \multirow[t]{2}{*}{$\begin{array}{l}\text { Average EPS change in } \mathrm{t}+1 \text { - instruments } \\
\text { revenue neutral }\end{array}$} & $\begin{array}{c}- \\
0.00575 * *\end{array}$ & $\begin{array}{c}- \\
0.00607 * *\end{array}$ \\
\hline & $(0.00247)$ & $(0.00251)$ \\
\hline \multirow[t]{2}{*}{ Revenue decreasing EPS tightening (MA) } & 0.0000456 & 0.000905 \\
\hline & $(0.00193)$ & $(0.00208)$ \\
\hline \multirow[t]{2}{*}{$\begin{array}{l}\text { Average EPS change in } \mathrm{t}+1 \text { - revenue } \\
\text { decreasing instruments }\end{array}$} & -0.000142 & $\begin{array}{c}- \\
0.0000518\end{array}$ \\
\hline & $(0.00110)$ & $(0.00112)$ \\
\hline Country fixed effects & Yes & Yes \\
\hline $\mathrm{N}$ & 282 & 282 \\
\hline Adj. R-squared & 0.686 & 0.703 \\
\hline
\end{tabular}

Note: Robust standard errors in parentheses; ${ }^{* * *}$ denotes statistical significance at the $1 \%$ level, ${ }^{* *}$ significance at $5 \%$ level, ${ }^{*}$ significance at $10 \%$ level.

(MA): denotes the moving average of the EPS change over three years (lag).

Baseline specification includes the following controls: Output gap, growth rate of average hours worked per employee, time trend, dummies for crisis years 2007 and 2008. Baseline + controls specification includes cyclically adjusted general government primary balance as percent of potential GDP (lag), trade openness (lag), industry share in \% of total activity (lag), business expenditure on R\&D as \% of GDP (lagged three years moving average), employment protection legislation (lag), product market regulation (lag) and the change in real oil price (lag). 
Table A2.6 Industry level: the double dividend hypothesis

\begin{tabular}{|c|c|c|c|c|c|c|c|c|}
\hline Column1 & 1 & 2 & 3 & 4 & 5 & 6 & 7 & 8 \\
\hline & Baseline & Baseline & $\begin{array}{l}\text { Baseline + } \\
\text { Regulation }\end{array}$ & $\begin{array}{l}\text { Baseline + } \\
\text { Regulation }\end{array}$ & $\begin{array}{l}\text { Baseline + } \\
\text { Country/ind } \\
\text { controls }\end{array}$ & $\begin{array}{c}\text { Baseline + } \\
\text { Country/ind } \\
\text { controls }\end{array}$ & $\begin{array}{l}\text { Full set of } \\
\text { controls }\end{array}$ & $\begin{array}{c}\text { Full set of } \\
\text { controls }\end{array}$ \\
\hline \multirow[t]{2}{*}{ Leader MFP growth } & $0.159 * * *$ & $0.135 * * *$ & $0.157 * * *$ & $0.133 * * *$ & $0.138 * * *$ & $0.113 * * *$ & $0.134 * * *$ & $0.110 * * *$ \\
\hline & $(0.0283)$ & $(0.0289)$ & $(0.0279)$ & $(0.0288)$ & $(0.0297)$ & $(0.0298)$ & $(0.0294)$ & (0.0299) \\
\hline \multirow[t]{2}{*}{$\begin{array}{l}\text { Distance to frontier } \\
\text { (lagged) }\end{array}$} & $0.179 * * *$ & $0.0934 * * *$ & $0.174 * * *$ & $0.0907 * * *$ & $0.179 * * *$ & $0.0941 * * *$ & $0.174 * * *$ & $0.0916 * * *$ \\
\hline & $(0.0274)$ & $(0.0133)$ & $(0.0261)$ & $(0.0128)$ & $(0.0269)$ & $(0.0128)$ & $(0.0254)$ & $(0.0123)$ \\
\hline \multirow[t]{2}{*}{$\begin{array}{l}\text { Revenue increasing } \\
\text { EPS tightening } \\
\text { (MA) }\end{array}$} & -0.0273 & -0.0224 & -0.0187 & -0.0153 & -0.00421 & 0.0159 & 0.00831 & 0.0275 \\
\hline & $(0.0463)$ & $(0.0416)$ & $(0.0472)$ & $(0.0419)$ & $(0.044)$ & $(0.0399)$ & $(0.045)$ & $(0.0407)$ \\
\hline \multirow[t]{2}{*}{$\begin{array}{l}\text { Effect of gap on rev- } \\
\text { increasing EPS } \\
\text { tightening (MA) }\end{array}$} & 0.0268 & 0.0153 & 0.0239 & 0.0115 & 0.0137 & 0.000637 & 0.0132 & -0.000261 \\
\hline & $(0.0232)$ & $(0.0222)$ & $(0.0225)$ & $(0.0217)$ & $(0.0187)$ & $(0.0178)$ & $(0.0184)$ & $(0.0176)$ \\
\hline \multirow[t]{2}{*}{$\begin{array}{l}\text { Revenue neutral EPS } \\
\text { tightening (MA) }\end{array}$} & $0.0977 * * *$ & $0.0890 * * *$ & $0.0992 * * *$ & $0.0908 * * *$ & $0.111 * * *$ & $0.106 * * *$ & $0.111 * * *$ & $0.107 * * *$ \\
\hline & $(0.0232)$ & $(0.0171)$ & $(0.0231)$ & $(0.0171)$ & $(0.0214)$ & $(0.016)$ & $(0.0212)$ & $(0.0159)$ \\
\hline \multirow[t]{2}{*}{$\begin{array}{l}\text { Effect of gap on rev- } \\
\text { neutral EPS } \\
\text { tightening (MA) }\end{array}$} & 0.0984 & 0.0618 & 0.0884 & 0.0561 & 0.0821 & 0.0113 & 0.0647 & -0.0019 \\
\hline & $(0.0933)$ & $(0.0843)$ & $(0.094)$ & $(0.0838)$ & $(0.0922)$ & $(0.0798)$ & $(0.093)$ & $(0.0799)$ \\
\hline \multirow[t]{2}{*}{$\begin{array}{l}\text { Revenue decreasing } \\
\text { EPS tightening } \\
\text { (MA) }\end{array}$} & -0.0778 & -0.0487 & -0.0738 & -0.0435 & -0.0436 & -0.0113 & -0.0437 & -0.0113 \\
\hline & $(0.0639)$ & $(0.061)$ & $(0.0627)$ & $(0.06)$ & $(0.0497)$ & $(0.0458)$ & $(0.0493)$ & $(0.0456)$ \\
\hline \multirow[t]{2}{*}{$\begin{array}{l}\text { Effect of gap on rev- } \\
\text { decreasing EPS } \\
\text { tightening (MA) }\end{array}$} & $-0.114 *$ & $-0.0928 * *$ & $-0.114^{*}$ & $-0.0928 * *$ & $-0.125 * *$ & $-0.112 * * *$ & $-0.126^{* *}$ & $-0.113 * * *$ \\
\hline & $(0.0621)$ & $(0.046)$ & $(0.0615)$ & $(0.0456)$ & $(0.0542)$ & $(0.038)$ & $(0.0525)$ & $(0.037)$ \\
\hline $\begin{array}{l}\text { Fixed Effects } \\
\text { Country*Industry }\end{array}$ & Yes & No & Yes & No & Yes & No & Yes & No \\
\hline Country & No & Yes & No & Yes & No & Yes & No & Yes \\
\hline Industry & No & Yes & No & Yes & No & Yes & No & Yes \\
\hline $\mathrm{N}$ & 2044 & 2044 & 2044 & 2044 & 1904 & 1904 & 1904 & 1904 \\
\hline adj. R squared & 0.128 & 0.176 & 0.132 & 0.182 & 0.134 & 0.198 & 0.137 & 0.202 \\
\hline
\end{tabular}

Note: Robust standard errors in parentheses and they are clustered at country-industry level; ${ }^{* \star *}$ denotes statistical significance at the $1 \%$ level, ${ }^{* *}$ significance at $5 \%$ level, ${ }^{*}$ significance at $10 \%$ level.

(MA): denotes the moving average of the EPS change over three years (lag).

Baseline specification includes the following controls: real GDP cycle, dummy for crisis and year trend. Baseline + Regulation includes: employment protection legislation (OECD EPL), product market regulation (OECD PMR) and country's degree of capital account openness (Chinn-Ito Index). Baseline + Country/ind. includes industry-specific time-varying controls, such as trade openness, R\&D expenditures, and real oil price. 
ECO/WKP(2014)75

\section{WORKING PAPERS}

The full series of Economics Department Working Papers can be consulted at www.oecd.org/eco/workingpapers

1178. The Indicators of the Economic Burdens of Environmental Policy Design - Results from the OECD Questionnaire

(December 2014) by Tomasz Koźluk

1177. Measuring Environmental Policy Stringency in OECD Countries-A Composite Index Approach (December 2014) by Enrico Botta and Tomasz Koźluk

1176. Do Environmental Policies Matter for Productivity Growth? Insights from new Cross-Country Measures of Environmental Policies

(December 2014) by Silvia Albrizio, Enrico Botta, Tomasz Koźluk and Vera Zipperer

1175. Making economic growth more socially inclusive

(December 2014) by Andrés Fuentes Hutfilter and Andreas Kappeler

1174. New tax and expenditure elasticity estimates for EU budget surveillance (forthcoming)

1173. Moving towards a more dynamic business sector in Spain

(November 2014) by Alberto Gonzalez Pandiella

1172. Better harnessing talent and knowledge to boost sustainable medium-growth in Spain (November 2014) by David Haugh and Ben Westmore

1171. The internet economy - regulatory challenges and practices

(November 2014) by Isabell Koske, Rosamaria Bitetti, Isabelle Wanner and Ewan Sutherland

1170. A revival of the private rental sector of the housing market? Lessons from Germany, Finland, the Czech Republic and the Netherlands

(October 2014) by Rik de Boer and Rosamaria Bitetti

1169. Secular stagnation: evidence and implications for economic policy

(October 2014) by Łukasz Rawdanowicz, Romain Bouis, Kei-Ichiro Inaba and

Ane Kathrine Christensen

1168. Investment gaps after the crisis

(October 2014) by Christine Lewis, Nigel Pain, Jan Strasky and Fusako Menkyna

1167. Factors behind the decline in real long-term government bond yield

(October 2014) by Romain Bouis, Kei-Ichiro Inaba, Łukasz Rawdanowicz and

Ane Kathrine Christensen

1166. The effect of the global financial crisis on the OECD potential output

(October 2014) by Patrice Ollivaud and David Turner

1165. Determinants of households' investment in energy efficiency and renewables - evidence from the OECD Survey on household environmental behaviour and attitudes 
(October 2014) by Nadia Ameli and Nicola Brandt

1164. Addressing high household debt in Korea

(September 2014) by Randall S. Jones and Myungkyoo Kim

1163. Reducing the high rate of poverty among the elderly in Korea

(September 2014) by Randall S. Jones and Satoshi Urasawa

1162. Promoting the financing of SMEs and start-ups in Korea

(September 2014) by Randall S. Jones and Myungkyoo Kim

1161. Fostering inclusive growth by promoting structural change in the business sector

(September 2014) by Rauf Gönenç, Oliver Röhn, Vincent Koen and Fethi Ögünç

1160. Reducing macroeconomic imbalances in Turkey

(September 2014) by Oliver Röhn, Rauf Gönenç, Vincent Koen and Evren Erdoğan Coşar

1159. Reinvigorating the EU Single Market

(September 2014) by Jean-Marc Fournier.

1158. An exploration of the determinants of the subjective well-being of Americans during the great recession

(August 2014) by Aida Caldera Sánchez and Caroline Tassot.

1157. Boosting the development of efficient SMEs in the Netherlands

(September) by Rafał Kierzenkowski and Jochebed Kastaneer

1156. Making the banking sector more resilient and reducing household debt in the Netherlands

(September 2014) by Rafał Kierzenkowski, Olena Havrylchyk and Pierre Beynet

1155. US long term interest rates and capital flows to emerging economies

(July 2014) by Eduardo Olaberria

1154. Productivity measurement with natural capital and bad outputs

(July 2014) by Nicola Brandt, Paul Schreyer and Vera Zipperer

1153. Reducing income inequality and poverty and promoting social mobility in Korea

(July 2014) by Randall S. Jones and Satoshi Urasawa

1152. Fostering a creative economy to drive Korean growth

(July 2014) by Randall S. Jones and Myungkyoo Kim

1151. Economic uncertainties and their impact on activity in Greece compared with Ireland and Portugal

(July 2014) by Jan-David Schneider and Claude Giorno

1150. Workplace stress in the United States: issues and policies

(July 2014) by Michael Darden

1149. Taxing the rent of non-renewable resource sectors: a theoretical note

(July 2014) by Julien Daubanes and Saraly Andrade de Sá 